\title{
Temporal variations in the hygroscopicity and mixing state of black carbon aerosols in a polluted megacity area
}

\author{
Kangning $\mathrm{Li}^{1}$, Xingnan Ye ${ }^{1}$, Hongwei Pang ${ }^{1}$, Xiaohui Lu ${ }^{1}$, Hong Chen ${ }^{1}$, Xiaofei Wang ${ }^{1,2}$, Xin Yang ${ }^{1,2}$, Jianmin Chen $^{1}$, \\ and Yingjun Chen ${ }^{2,3}$ \\ ${ }^{1}$ Shanghai Key Laboratory of Atmospheric Particle Pollution and Prevention, Department of Environmental Science and \\ Engineering, Fudan University, Shanghai 200433, China \\ ${ }^{2}$ Shanghai Institute of Pollution Control and Ecological Security, Shanghai 200092, China \\ ${ }^{3}$ College of Environmental Science and Engineering, Tongji University, Shanghai 200092, China
}

Correspondence: Xiaofei Wang (xiaofeiwang@fudan.edu.cn) and Xin Yang (yangxin@fudan.edu.cn)

Received: 18 June 2018 - Discussion started: 25 June 2018

Revised: 14 September 2018 - Accepted: 8 October 2018 - Published: 23 October 2018

\begin{abstract}
Black carbon (BC) aerosols in the atmosphere strongly affect radiative forcing. They are mainly removed from the air by wet deposition, and their lifetime is controlled by their water uptake ability or hygroscopicity, which is a function of aerosol mixing states. It is well known that atmospheric aging processes coat various materials on $\mathrm{BC}$ aerosols and affect their mixing states and hygroscopicity. However, detailed relations between the aging processes and the hygroscopicity and mixing state of $\mathrm{BC}$ aerosol particles in polluted city areas are not well understood. Here, we studied the temporal variation in hygroscopicity and its correlation with the mixing state of ambient $\mathrm{BC}$ particles during the summer of 2017 in Shanghai, China, using a hygroscopic tandem differential mobility analyzer inline with a singleparticle soot photometer (HTDMA-SP2 system) as well as a single-particle aerosol mass spectrometer (SPAMS). BC particles with 120, 240, and $360 \mathrm{~nm}$ in dry diameter were humidified at relative humidity $(\mathrm{RH})=85 \%$. After humidification, particles with growth factors (GFs) of 1.0, 1.2, and 1.4, representing the BC particles with different hygroscopicities (hydrophobic, transition, and hydrophilic modes, respectively), were analyzed with a SP2 to obtain their BC mixing states. The diurnal trends in coating thickness and chemical mixing state show that coating materials of BC particles were distinct between daytime and nighttime. The differences were associated with the hygroscopicity of BC particles. Singleparticle mass spectrometry and other chemical characterization techniques revealed that with lower temperature and higher RH during nighttime, formation or condensation of
\end{abstract}

nitrates resulted in an enhanced hygroscopicity of BC particles. During daytime, secondary organic carbon formation was mainly responsible for the change of hygroscopicity of $\mathrm{BC}$ particles. Due to the high hygroscopicity of inorganic nitrate, a thinner nitrate coating on $\mathrm{BC}$ particles could convert fresh $\mathrm{BC}$ particles to aged hygroscopic ones during nighttime while a thicker coating layer of secondary materials was required to reach the same overall hygroscopicity during daytime because of the participation of secondary organic carbon. Different atmospheric aging processes between daytime and nighttime led to the change of BC particles' mixing states, which play a fundamental role in determining their hygroscopicity. To our knowledge, this is the first report of links between temporal variations in the hygroscopic growth of $\mathrm{BC}$ particles and atmospheric aging processes in polluted environments. These findings have significant ramifications in understanding the aging process, wet removal, and climate effects of $\mathrm{BC}$ particles.

\section{Introduction}

Black carbon (BC) aerosols are a strong light-absorbing component in the atmosphere and a major contributor to positive radiative forcing (Bond et al., 2013; Change, 2015; Kondo, 2015). They are mainly generated from incomplete combustion of fossil fuels and biomass. Fresh BC emissions from traffic are hydrophobic (Lammel et al., 1995; Dusek et al., 2006). However, the particles can be enhanced by internally 
mixing with secondary materials through atmospheric aging processes (Schneider et al., 2005; Shiraiwa et al., 2007; Matsui et al., 2013; Pratt et al., 2011). Hygroscopicity of BC aerosol significantly affects its removal rate through wet deposition, absorption in the human respiratory tract (Löndahl et al., 2007), optical properties (Chen et al., 2012), and their surface reactivity (Mogili et al., 2006). Therefore, it is critical to understand the relations between the atmospheric aging processes and the hygroscopicity of $\mathrm{BC}$ aerosols. Atmospheric aerosols, including $\mathrm{BC}$ particles, always have various sizes with distinct chemical compositions. To better understand or describe an aerosol population, mixing state is often used. The definition of mixing state, provided by Winkler (1973), refers to both internal and external mixtures in aerosols. In an external mixture, individual particles in a given size range consist of different chemical species. Chemical composition of particulate mass in that size range will be determined by the relative contributions of the chemically distinct particles. In an internal mixture, however, all particles in a given size range are composed of the same mixture of two or more chemical compounds (Heintzenberg et al., 1990). The mixing state of atmospheric BC particles is closely linked to their sources and aging processes (Weingartner et al., 1997; Gysel et al., 2003; Petzold et al., 2005; Chirico et al., 2010; Heringa et al., 2011). Aerosol hygroscopicity is determined by the chemical composition of each individual particle (Heintzenberg et al., 1990; Gysel et al., 2003; McMeeking et al., 2011; Liu et al., 2013). Thus, aerosol mixing states play a critical role in determining the hygroscopicity of BC particles.

Many studies have reported the mixing state of atmospheric BC particles. For example, aerosol's mixing state can be determined using a hygroscopic tandem differential mobility analyzer (HTDMA) (Swietlicki et al., 2008) or a combined volatility-hygroscopicity TDMA (VHTDMA) (e.g., Johnson, 2005). Shiraiwa et al. (2007) investigated the evolution of mixing state of BC using a SP2 in the polluted air transported from the Tokyo area in summer. The fraction of thickly coated BC with a core diameter $\left(D_{\mathrm{C}}\right)$ of $180 \mathrm{~nm}$ increased at a rate of $1.9 \% \mathrm{~h}^{-1}$. The increase rates were lower for larger $D_{\mathrm{C}}$ values (Shiraiwa et al., 2007). Healy et al. (2012) used an aerosol time-of-flight mass spectrometer (ATOFMS) to study the mixing state of BC particles in Paris. The smaller BC particles $\left(D_{\mathrm{va}} \leq 400 \mathrm{~nm}\right)$ were mainly externally mixed, indicating they were from local or regional sources, while bigger BC particles $\left(D_{\mathrm{va}} \geq 400 \mathrm{~nm}\right)$ were mainly internally mixed with nitrate, indicating they were from medium to long-range transport. Kuwata and Kondo (2008) conducted volatility TDMA (VTDMA) measurements and showed that the aerosol was often an external mixture of less and more-volatile particles.

According to our knowledge, there are only a few direct measurements of BC particles' hygroscopic properties in the atmosphere. One of the previously used techniques was coupling hygroscopic measurements with a VTDMA system. It was found that the less volatile aerosol components were mainly composed of $\mathrm{BC}$ at close proximity to urban environments (Kuwata et al., 2007; Rose et al., 2011). The relationship between hygroscopicity and mixing state of BC aerosols had been studied. BC particles exposed to subsaturated sulfuric acid vapor exhibit a large change in morphology. These particles are very hygroscopic and act as efficient cloud condensation nuclei. Coating with sulfuric acid and subsequent hygroscopic growth increase their light-scattering coefficient by 10 -fold and light absorption coefficient by nearly 2 -fold at relative humidity $(\mathrm{RH})=80 \%$ compared to uncoated $\mathrm{BC}$ particles (Zhang et al., 2008). Herich et al. (2008) combined an ATOFMS with a HTDMA to investigate the mixing state and hygroscopicity of BC-containing particles at an urban site in Zurich, Switzerland. The result shows that most BC-containing particles internally mixed with organics and combustion species $\left({ }^{-26} \mathrm{CN}^{-}\right.$and $\left.{ }^{-42} \mathrm{CNO}^{-}\right)$. They have lower hygroscopicity compared with mixed sulfate and nitrate (Herich et al., 2008). With a similar setup, our previous study finds that condensation of amine and secondary inorganic species would enhance the hygroscopicity of submicron particles, including BC particles (Wang et al., 2014). Laborde et al. connected a SP2 downstream of a HTDMA $(\mathrm{RH}=90 \%)$ and show that the majority of urban aerosol particles with high hygroscopicity (growth factor, $\mathrm{GF} \approx 1.6$ ) do not contain a detectable refractory $\mathrm{BC}(\mathrm{rBC})$ core, while hydrophobic or less hygroscopic particles $(1.1 \leq \mathrm{GF} \leq 1.2)$ have a BC core with no or little coating of soluble species (Laborde et al., 2013). Similarly, by coupling a SP2 with a HTDMA, McMeeking et al. (2011) introduced a method for measuring the hygroscopicity of externally and internally mixed $\mathrm{BC}$ particles. They tested this technique using uncoated and coated laboratory-generated model BC compounds. The obtained information is compared to the hygroscopicity distribution of ambient $\mathrm{BC}$ aerosols. Their results suggest that the dominant fraction of the $\mathrm{BC}$ particles does not readily act as cloud condensation nuclei at $0.2 \%$ supersaturation in an urban area. In addition, Liu et al. (2013) deployed a similar instrument setup and investigated the relation between the hygroscopic properties and mixing state of BC particles (Liu et al., 2013). It shows that the GF of BC particles was influenced by the composition of soluble materials.

These previous studies have relied on real-time hygroscopicity measurements but usually without detailed temporal information on changes of mixing state of $\mathrm{BC}$ particles. Time-resolved information on aerosol mixing state would be very useful to identify their sources and aging processes. During summertime in heavily polluted areas, atmospheric aging processes could be much more complex due to higher temperature, higher pollutant concentrations, and stronger sunlight radiation. However, according to our knowledge, few studies have reported time-resolved analysis on the mixing state and hygroscopicity of BC particles of particular GFs during summertime. Therefore, with high- 


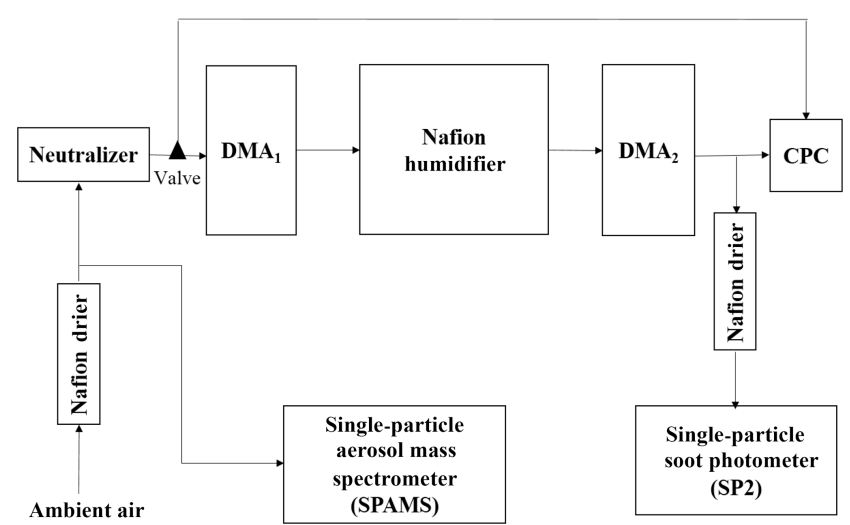

Figure 1. Schematic diagram of experimental setup.

time-resolution single-particle analysis, this field study has aimed to determine the relations between BC particle hygroscopicity and real time mixing state measurement in Shanghai, a heavily polluted megacity area. It would provide more insights on the effects of atmospheric processes on hygroscopicity of BC particles.

\section{Experimental section}

\subsection{HTDMA-SP2 system}

Temporal variation in $\mathrm{BC}$ aerosol mixing state and hygroscopic property were measured using a custom-built HTDMA-SP2 system (Fig. 1). Similar to systems that couple an HTDMA with another instrument, such as those used by Herich et al. (2008), Zelenyuk et al. (2008), and Wang et al. (2014), our system used SP2 (DMT, Boulder, CO, USA) downstream of a HTDMA to measure rBC content as a function of hygroscopicity. The first DMA in the HTDMA system selects monodisperse dried particles. Then the selected aerosols are humidified at a specified RH $(\mathrm{RH}=85 \%$ in this study). The size distribution of humidified (wet) particles is measured with a scanning mobility particle sizer (SMPS), which includes another DMA and a condensation particle counter (CPC, model 3771, TSI Inc.). GF is the ratio between particle wet size and dry size. The two DMAs were operated with recirculating sheath flows and a sheath-to-sample flow ratio of $10: 1$. The HTDMA is encapsulated in a thermostatted box to reduce temperature fluctuations. The DMA housing temperature was controlled at $20^{\circ} \mathrm{C}$. Aerosol flow was set at $0.43 \mathrm{~L} \mathrm{~min}^{-1}$ (the sum of the CPC $\left(0.4 \mathrm{~L} \mathrm{~min}^{-1}\right.$ ) and the SP2 $\left(0.03 \mathrm{~L} \mathrm{~min}^{-1}\right)$ flow rates). The hygroscopicity measurement was calibrated using $\left(\mathrm{NH}_{4}\right)_{2} \mathrm{SO}_{4}$ particles. The SP2 identifies BC-containing particles at each selected GF. The water uptake properties of $\mathrm{BC}$ particles can be linked directly to the mixing state measured by SP2.

SP2 can measure number and mass size distribution of rBC-containing particles (Baumgardner et al., 2004; Schwarz et al., 2006). Briefly, SP2 detects incandescence and scattering light signals of rBC-containing particles induced by a $1064 \mathrm{~nm} \mathrm{Nd:YAG} \mathrm{intra-cavity} \mathrm{laser.} \mathrm{The} \mathrm{mass} \mathrm{of} \mathrm{rBC}$ is proportional to the intensity of the incandescence signal. A particle with an incandescence signal (above a threshold) is treated as an $\mathrm{rBC}$ particle, while a particle that only exhibits scattering signal is considered a non-rBC particle. SP2 detection efficiency was close to unity for larger $\mathrm{rBC}$ particles. The minimum rBC mass that could be observed with nearunity detection efficiency was $\sim 0.7 \mathrm{fg} \mathrm{rBC}$, corresponding to a $90 \mathrm{~nm}$ mass-equivalent diameter; the detection efficiency declined rapidly at lower sizes (Gong et al., 2016). The total ambient mass concentrations of $\mathrm{rBC}$ were possibly underestimated because of the reduced detection efficiency for small rBC particles (Schwarz et al., 2006; McMeeking et al., 2010).

The conversion from $\mathrm{rBC}$ mass to the effective $\mathrm{rBC}$ core diameter requires us to assume an effective density for $\mathrm{rBC}$ cores in the particles. In this study, an effective density of $1.8 \mathrm{~g} \mathrm{~cm}^{-3}$ was used to convert the ambient $\mathrm{rBC}$ mass to the mass-equivalent diameter. This value was recommended by many previous studies (Bond and Bergstrom, 2006; Gong et al., 2016).

The scattering properties of externally and internally mixed rBC particles may be distorted due to particle mass loss induced by laser heating in SP2. Thus, scattered light from an $\mathrm{rBC}$ particle may not yield a full Gaussian waveform. The Gaussian scattering function was reconstructed from the leading edge of the scattering signal (before particle is heated by the laser), which was measured with a twoelement avalanche photodiode (APD). This method (leadingedge-only fit or LEO fit) can determine the scattering properties of individual rBC particles more accurately (Gao et al., 2007). Optical diameter of an rBC particle $\left(D_{\mathrm{p}}\right)$ was derived from Mie theory with the LEO fitted scattering signal and rBC core size $\left(D_{\mathrm{c}}\right)$ (Moteki et al., 2010; Liu et al., 2014; Laborde et al., 2013). The absolute coating thickness of an rBC particle was calculated as $\left(D_{\mathrm{p}}-D_{\mathrm{c}}\right) / 2$, based on the assumption of a concentric core-shell morphology. However, rBC aging in the atmosphere may result in an imperfect coreshell structure (Matsui et al., 2013).

In this study, ambient particles with three electrical mobility sizes $(120,240$, and $360 \mathrm{~nm}$ in dry diameter) were selected first by a DMA, then humidified at a $\mathrm{RH}=85 \%$. For the measurement of the overall hygroscopic distribution of total ambient particles (such as Fig. 3a), the second DMA was operated in a continuous scanning mode. For the measurement of temporal trends in the hygroscopic distribution, the second DMA was operated in a stepped mode by sending particles with fixed GFs of 1.0, 1.2, and 1.4 (representing hydrophobic, transition, and hydrophilic modes, respectively) to the CPC and SP2. 


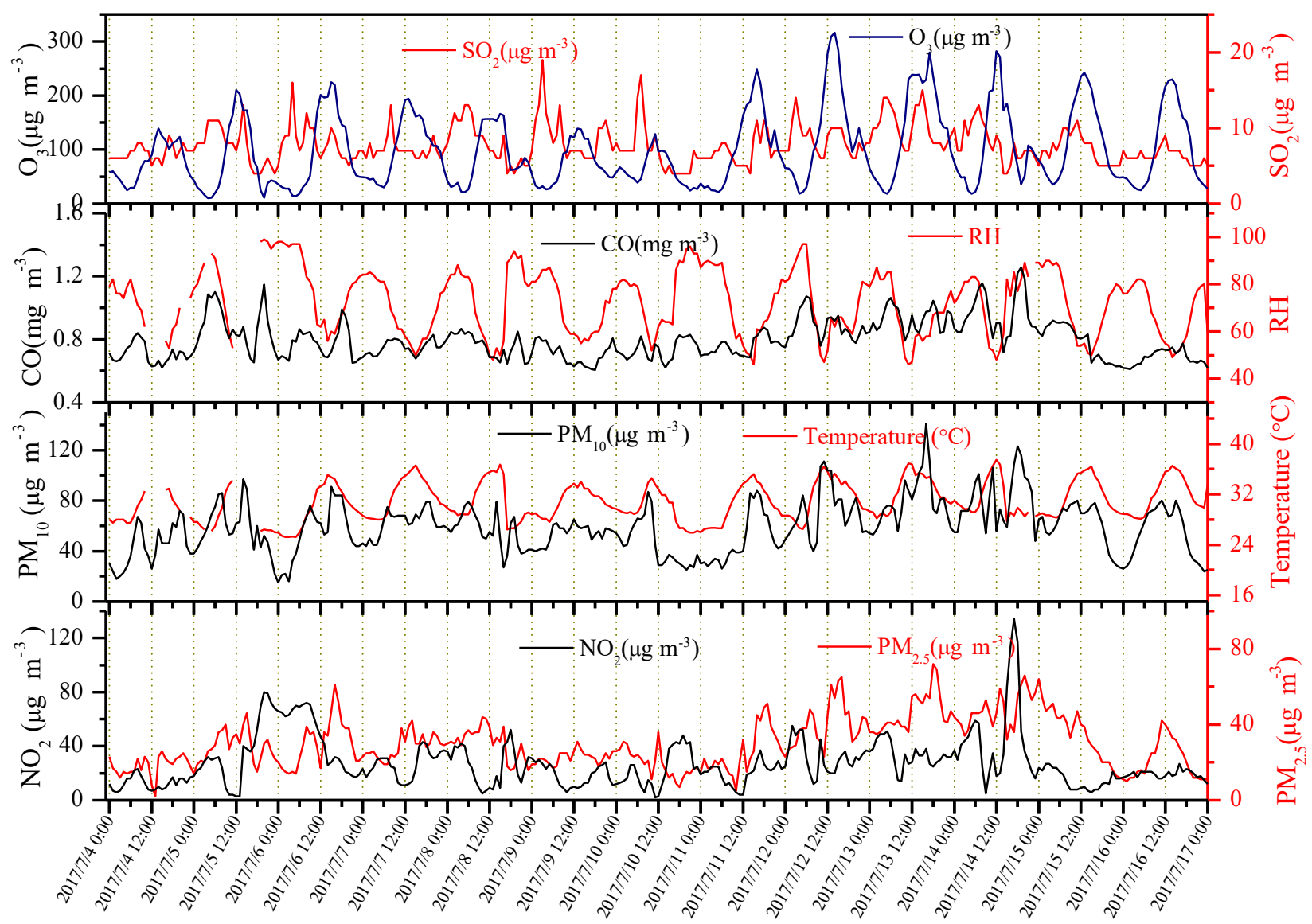

Time

Figure 2. Temporal profiles of gaseous pollutants $\left(\mathrm{O}_{3}, \mathrm{SO}_{2}, \mathrm{CO}\right.$, and $\left.\mathrm{NO}_{2}\right)$, temperature, relative humidity $(\mathrm{RH})$, and $\mathrm{PM} 2.5$ and $\mathrm{PM} 10$ mass concentrations.

\subsection{Single-particle aerosol mass spectrometer (SPAMS)}

A single-particle aerosol mass spectrometer (SPAMS Hexin Analytical Instrument Co., Ltd., China) was used in parallel to the HTDMA-SP2 system. The SPAMS first measures the size of a single aerosol particle. Then, it uses a $266 \mathrm{~nm}$ laser to disintegrate the particle and ionize its chemical compounds, of which mass-to-charge ratios $(\mathrm{m} / \mathrm{z})$ and concentration are determined with a bipolar time-of-flight mass spectrometer. Detailed information on the SPAMS has been described elsewhere (Li et al., 2011).

In this work, a total of 158410 individual particle mass spectra were collected, accounting for about $56 \%$ of all the particles that were sized in the SPAMS. Elemental carbon (EC) ion clusters have been considered an important marker for BC aerosols (Gong et al., 2016). Using $\mathrm{C}_{n}^{+}(n=1,2$, $3 . .$.$) as the BC marker, a total of 64368$ BC-containing particles were identified, accounting for about $40.1 \%$ of sampled particles. The mass spectra of $\mathrm{BC}$-containing particles were classified into several types based on their similarities using a clustering algorithm called adaptive resonance theory (ART2a) (Song et al., 1999). Similar to previous studies (Huang et al., 2013; Zhai et al., 2017; Gong et al., 2016; Spencer et al., 2007), the vigilance factor, learning rate, and iterations for the ART-2a algorithm were set to $0.85,0.05$, and 20, respectively. Finally, five particle types were manually combined based on the similarity of their chemical nature.

Noticeably, the particles with a mobility size at $120 \mathrm{~nm}$ cannot be detected by the SPAMS, as they were smaller than the lower limit $(200 \mathrm{~nm})$ of the size range of the SPAMS. According to Slowik's study, the vacuum aerodynamic diameter $\left(d_{\mathrm{va}}\right)$ of compact aggregated BC particles was linearly proportional to mobility diameter $\left(d_{\mathrm{m}}\right)$, specifically, $d_{\mathrm{va}}=1.3 \cdot d_{\mathrm{m}}$ (Slowik et al., 2004). Here we assume that most detected BC particles follow this relation $\left(d_{\mathrm{va}}=1.3 \cdot d_{\mathrm{m}}\right)$. In this study, only particles with $D_{0}=120,240$, and $360 \mathrm{~nm}$ were studied with the HTDMA-SP2 system. These mobility sizes correspond to $d_{\mathrm{va}}=150,312$ and $468 \mathrm{~nm}$, respectively. Thus, the SPAMS cannot provide mixing state infor- 


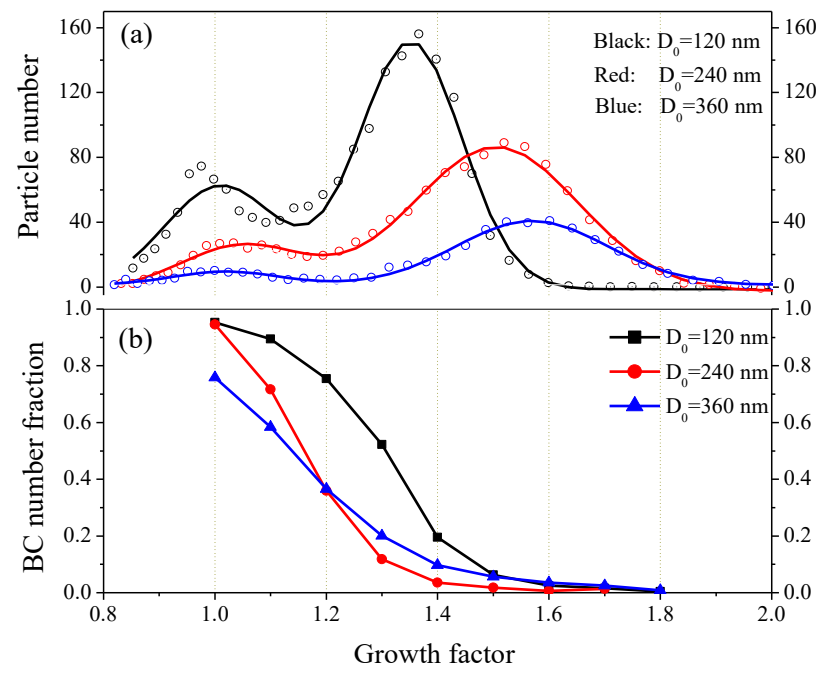

Figure 3. Averaged hygroscopic growth distributions of (a) total ambient particles and (b) $\mathrm{BC}$ particles at $\mathrm{RH}=85 \%$ for three selected sizes $\left(D_{0}=120,240\right.$, and $\left.360 \mathrm{~nm}\right)$.

mation for particles with $d_{\mathrm{va}}=150 \mathrm{~nm}\left(d_{\mathrm{m}}=120 \mathrm{~nm}\right)$, which was out of the SPAMS detection range (200 to $2000 \mathrm{~nm}$ ).

\subsection{Other instruments}

\subsubsection{OC / EC analyzer}

Hourly mass concentrations of EC and organic carbon (OC) were measured using a semicontinuous OC/EC analyzer (model 4, Sunset Laboratory Inc., Portland, USA) based on the National Institute of Occupational Safety and Health thermal-optical transmittance measurement protocol (NIOSH 5040), with a $\mathrm{PM}_{2.5}$ impactor inlet. Detailed information can be found in a previous publication (Wang et al., 2016a). Concentration of secondary organic carbon (SOC) was estimated using the method of the minimum ratio of OC / EC (Chou et al., 2010), which is calculated by the following equation.

$\mathrm{SOC}=\mathrm{OC}_{\text {total }}-\mathrm{EC} \cdot(\mathrm{OC} / \mathrm{EC})_{\mathrm{pri}}$,

where $\mathrm{OC}$ and $\mathrm{EC}$ are the measured hourly mass concentrations of $\mathrm{OC}$ and $\mathrm{EC}$. $(\mathrm{OC} / \mathrm{EC})_{\text {pri }}$ is the $\mathrm{OC} / \mathrm{EC}$ ratio in primarily emitted combustion aerosols. At urban locations, the $(\mathrm{OC} / \mathrm{EC})_{\text {pri }}$ was assumed to be the minimum value of the $\mathrm{OC} / \mathrm{EC}$ ratio throughout the whole study sampling period (Cao et al., 2013). The OC vs. EC plot is displayed in Fig. S1 in the Supplement. We use the minimum value 2.2 as the $(\mathrm{OC} / \mathrm{EC})_{\text {pri }}$ in this work.

\subsubsection{Monitor for AeRosols and Gases in Air (MARGA)}

A Monitor for Aerosols and Gases in Air (MARGA, Applikon Analytical B. B. Corp., ADI 2080, the Netherlands), with a $\mathrm{PM}_{2.5}$ cyclone impactor, was deployed to measure the concentrations of inorganic ionic species (i.e., $\mathrm{SO}_{4}^{2-}, \mathrm{NO}_{3}^{-}$, and $\mathrm{NH}_{4}^{+}$) in $\mathrm{PM}_{2.5}$. Detailed description about the MARGA is available in the previous publication (Du et al., 2010).

\subsection{Sampling period and site}

The measurements of the relationship between mixing state and hygroscopicity of BC particles varying with time were carried out from 4 to 16 July 2017 using a SPAMS and a HTDMA-SP2 system. The sampling site is located at the Department of Environmental Science and Engineering on the main campus of Fudan University $\left(31.30^{\circ} \mathrm{N}, 121.5^{\circ} \mathrm{E}\right)$, and it is surrounded by residential and commercial areas. An elevated road (the Middle Ring Line) with heavy traffic is $\sim 400 \mathrm{~m}$ away from the sampling location.

\subsection{Meteorology}

The meteorology and air quality information were obtained at a nearby air quality monitoring station, which is operated by the Shanghai Environmental Monitoring Center (Yangpu site) (http://www.semc.com.cn/aqi/home/Index.aspx, last access: 29 May 2018). The station was $3.3 \mathrm{~km}$ from the sampling site. Temporal profiles of measured gaseous pollutants $\left(\mathrm{O}_{3}, \mathrm{SO}_{2}, \mathrm{CO}\right.$, and $\left.\mathrm{NO}_{2}\right)$, temperature, $\mathrm{RH}, \mathrm{PM}_{2.5}$, and hourly $\mathrm{PM}_{10}$ mass concentrations from 4 to 16 July 2017 are shown in Fig. 2. The temperature and RH varied between 24.1 and $38.0^{\circ} \mathrm{C}$ and $46 \%$ and $100 \%$, with an average of $30.4^{\circ} \mathrm{C}$ and $74.1 \%$, respectively, during the sampling period. Figure 2 shows that the temperature was negatively correlated with $\mathrm{RH}$ but positively correlated with $\mathrm{O}_{3}$ mass concentration. Hourly $\mathrm{O}_{3}$ concentration usually peaked in the afternoon during this period. Its maximum value reached $316 \mu \mathrm{g} \mathrm{m}^{-3}$ at 14:00 LT on 12 July, showing extremely active photochemical activities in this afternoon. The maximum value of $\mathrm{PM}_{2.5}$ reached $72 \mu \mathrm{g} \mathrm{m}^{-3}$ at 18:00 LT on 13 July with an average of $29.2 \mu \mathrm{g} \mathrm{m}^{-3}$. Meanwhile, $\mathrm{PM}_{10}$ varied from 15 to $141 \mu \mathrm{g} \mathrm{m}^{-3}$, with an average of $57.9 \mu \mathrm{g} \mathrm{m}^{-3}$.

\section{Results and discussion}

The focus of this paper is temporal variation in hygroscopicity and mixing states of ambient BC particles. Due to the slow scanning rate of DMA voltage and sampling time requirement of SP2, obtaining temporal information of $\mathrm{BC}$ concentrations requires the DMA size selection to be fixed for a certain amount of time. Therefore, for the HTDMA-SP2 system, only one size $\left(D_{0}\right)$ was studied for each sampling period. Specifically, $D_{0}=120,240$, and $360 \mathrm{~nm}$ were measured during 4 July 2017 06:00:00 LT7 July 2017 05:00:00 LT, 7 July 2017 06:00:00 LT10 July 2017 05:00:00 LT, and 10 July 2017 06:00:00 LT16 July 2017 05:00:00 LT, respectively. 
(a)

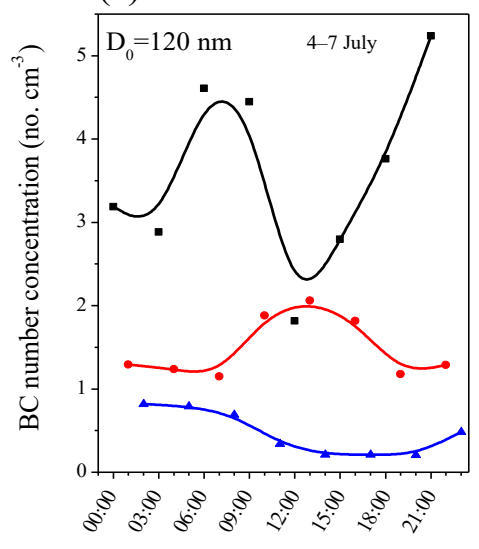

(b)

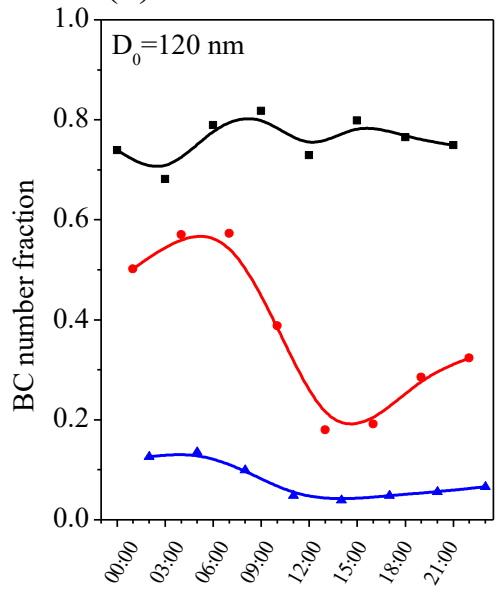

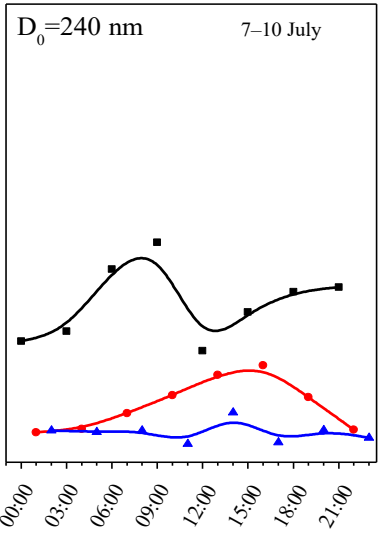

Time

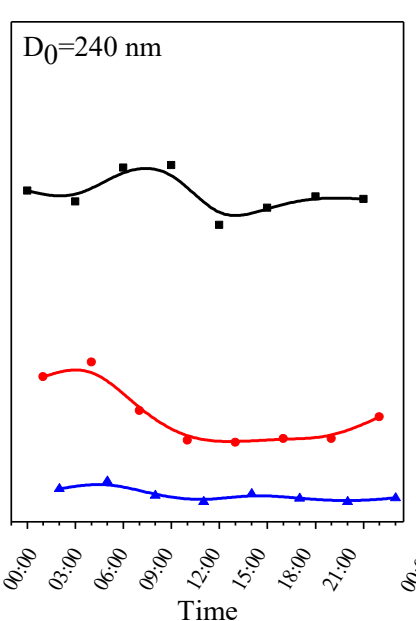

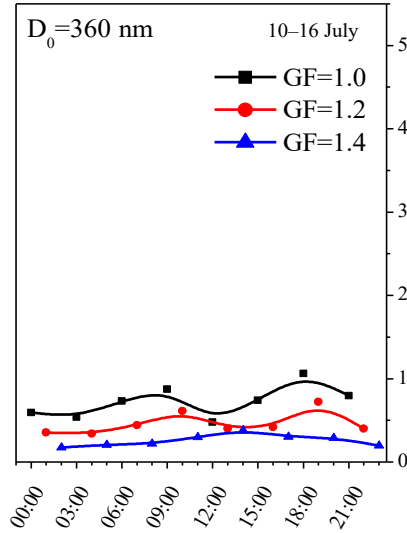

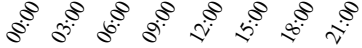

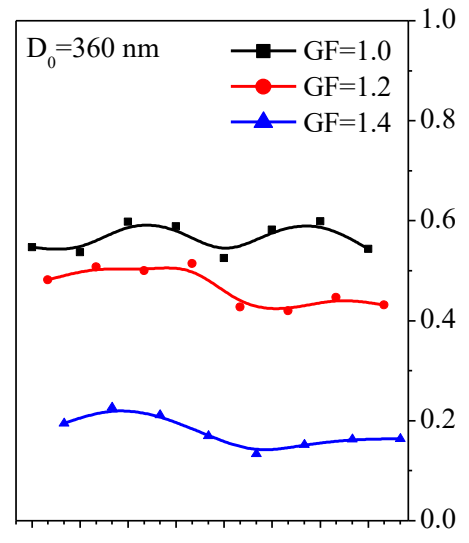

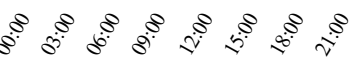

Figure 4. Diurnal variations in $\mathrm{BC}$ (a) number concentration and (b) number fraction (the ratio of the number concentration of $\mathrm{BC}$ particles to that of total particles at a certain $D_{0}$ and GF) for three selected sizes.

We studied three GFs $(\mathrm{GF}=1.0,1.2$, and 1.4) for each $D_{0}$. The GF selection was based on the GF size distribution of $\mathrm{BC}$ particles. A general picture of hygroscopicity of total sampled ambient particles is shown in Fig. 3a, which illustrates averaged hygroscopic GF distributions at three selected sizes $\left(D_{0}=120,240\right.$, and $\left.360 \mathrm{~nm}\right)$. All three GF curves featured a bimodal distribution, which contained a hydrophobic mode peak at $\mathrm{GF}=\sim 1.0$ and a hydrophilic mode peak at larger GFs (1.3-1.6). Clearly, the hygroscopic particles were typically more abundant than the hydrophobic ones. These hygroscopic particles featured a size-dependent hygroscopic growth, significantly shifting to a larger GF with increasing particle size. This feature was conventionally attributed to a size-dependent chemical composition (Swietlicki et al., 2008; Ye et al., 2013). In contrast, hygroscopic GF distributions of $\mathrm{BC}$ particles only show one mode (Fig. 3b). The GF curve of $\mathrm{BC}$ particles peaked at $\mathrm{GF}=\sim 1.0$. The $\mathrm{BC}$ containing number fraction decreased sharply for larger GFs.
When GF was greater than 1.4, few BC particles were detected by the SP2.

GFs of 1.0, 1.2, and 1.4 were selected to represent hydrophobic, transition, and hydrophilic modes for BC particles, respectively. Higher GFs (GF $>1.4$ ) were not selected due to the low BC-containing number fractions at these GFs. For each day, the sampling was divided into eight $3 \mathrm{~h}$ sampling periods. Three GFs (GF $=1.0,1.2$, and 1.4) were set sequentially for $1 \mathrm{~h}$ during each sampling period.

Here, the diurnal trend in (in Sect. 3.1) and classification of (in Sect. 3.2) BC particles are described and discussed in detail. Then, the relations between mixing state and hygroscopicity of BC particles are elucidated (in Sect. 3.3). 


\subsection{Diurnal variations in BC particles with different hygroscopicities}

\subsubsection{Diurnal variation in hydrophobic-mode BC particles}

The averaged diurnal patterns of the number concentration and number fraction of $\mathrm{BC}$ particles are shown in Fig. 4a and $b$, respectively. The number fraction of $\mathrm{BC}$ particles is defined as the ratio of the number concentration of sampled $\mathrm{rBC}$ particles to that of total samples, including $\mathrm{rBC}$ and non-BC particles, at a certain $D_{0}$ and GF. The majority of hydrophobic-mode $(\mathrm{GF}=1.0) \mathrm{BC}$ particles typically exhibited two peaks for all three $D_{0}$ values (Fig. 4a). They were likely to be freshly emitted from combustion sources (McMeeking et al., 2011). The number concentrations of hydrophobic BC particles reached their first peak in the morning around 06:00 to 09:00 local time (LT) and were then followed by a dip in the afternoon around 12:00 to 17:00 LT. The hydrophobic BC particles reached the second peak in the evening and then slowly decreased during the night. This trend is similar to that found in some field studies in other city areas, such as Shenzhen and Xiamen in China (Huang et al., 2012; Wang et al., 2016b). The elevated BC particle number concentration in the morning and early evening can be explained by increases in local anthropogenic emissions, especially those from rush hour traffic (Dreher et al., 1998; Allen et al., 1999; Bhugwant et al., 2000). This trend presumably was also intensified by lower boundary layer heights at those times.

As shown in Fig. 4b, hydrophobic BC particles accounted for the largest percentage among three GFs for all $D_{0}$ values. However, the number fractions of hydrophobic BC particles decreased with the increased $D_{0}$. For $D_{0}=120,240$, and $360 \mathrm{~nm}$, the maximum number fractions of the hydrophobic $\mathrm{BC}$ particles were $\sim 80 \%, 70 \%$, and $60 \%$, respectively. One possible reason is that the majority of fresh $\mathrm{BC}$ particles' diameters are smaller than $200 \mathrm{~nm}$ (Kondo et al., 2006), corresponding to our finding that relatively lower fractions of $\mathrm{BC}$ particles were detected at larger sizes. In addition, factors affecting the $\mathrm{BC}$ number fractions at $\mathrm{GF}=1.0$ may also be related to the behavior of non-BC-containing particles and their size dependence.

\subsubsection{Diurnal variations in transition and hydrophilic-mode BC particles}

The transition and hydrophilic-mode BC particles likely originated from aged particles. Condensation of hydrophilic secondary materials (e.g., sulfate, nitrate, and secondary organic compounds) would significantly enhance the water uptake ability of BC particles. As shown in Fig. 4a, the number concentrations of some transition and hydrophilic-mode BC particles (like transition mode for 120 and $240 \mathrm{~nm} \mathrm{BC}$ particles) showed a clear daily maximum during 12:00-15:00 LT
(Fig. 4a). This trend could be explained by the intense aging processes during this time when sunlight intensity and atmospheric oxidants' concentration reach their peak values. However, the number concentration of transition and hydrophilic-mode BC particles could be affected by other atmospheric aging processes. For example, nitrate formation could be significantly enhanced during nighttime due to the hydrolysis of $\mathrm{N}_{2} \mathrm{O}_{5}$ (Mozurkewich et al., 1988; Wang et al., 2009, 2016a). This process would make more transition and hydrophilic-mode $\mathrm{BC}$ particles during nighttime. To understand their diurnal trends, the measurement of their chemical compositions and mixing states is essential, which will be discussed in Sect. 3.3.

Figure $4 \mathrm{~b}$ also shows the diurnal variations in number fractions of transition and hydrophilic-mode $\mathrm{BC}$ particles. Unlike the hydrophobic mode $\mathrm{BC}$ particles, the transition and hydrophilic-mode ( $\mathrm{GF}=1.2$ and 1.4) $\mathrm{BC}$ particles with larger sizes tended to contribute higher number fractions of total particles. This trend was more pronounced for the hydrophilic mode $(\mathrm{GF}=1.4)$ : the maximum number fractions of BC particles were $\sim 10 \%, 10 \%$, and $20 \%$ for $D_{0}=120$, 240 , and $360 \mathrm{~nm}$, respectively. One possible reason is that the sizes of fresh BC particles are likely to be small. The median diameter of $\mathrm{BC}$ particles originating from traffic emissions is usually < $200 \mathrm{~nm}$ (Harris et al., 2001; Zervas et al., 2006; Xue et al., 2015). They have to grow to larger sizes (e.g., $360 \mathrm{~nm}$ ) through aging/coating, which also increases their hygroscopicity. Another possible reason is that these hydrophilic $\mathrm{BC}$ particles were from a different source. A candidate is biomass burning (BB) aerosols, which have slightly higher hygroscopicity than those from traffic emissions (Laborde et al., 2013). Detailed discussion of BB aerosol will be shown in Sect. 3.2.

In addition, the diurnal variations in the $\mathrm{BC}$ particle number fraction showed that during nighttime, a larger proportion of $\mathrm{BC}$ particles were in hygroscopic mode compared to during daytime, indicating that hygroscopicity of $\mathrm{BC}$ at night was much stronger than that in the daytime. The main reason will be discussed in Sect. 3.3.

\subsubsection{Diurnal variations in $\mathrm{rBC}$ core diameter and coating thickness}

The rBC core diameter $\left(D_{\mathrm{c}}\right)$ can be obtained if a single particle $\mathrm{BC}$ mass is known and assuming that the core is spherical and $\mathrm{BC}$ density is $1.8 \mathrm{~g} \mathrm{~cm}^{-3}$. The corresponding coating thickness is $\left(D_{\mathrm{p}}=D_{\mathrm{c}}\right) / 2$ (Gong et al., 2016). Diurnal variations in average $\mathrm{rBC}$ core diameter and coating thickness at different GFs are displayed in Fig. 5a and b, respectively. For a certain BC particle size, a larger core size and a thinner coating thickness corresponded to BC particles with lower hygroscopicity (e.g., $\mathrm{GF}=1.0$ ). When $\mathrm{BC}$ particles became more hygroscopic (i.e., GF increases), the coating thickness increased. 
(a)
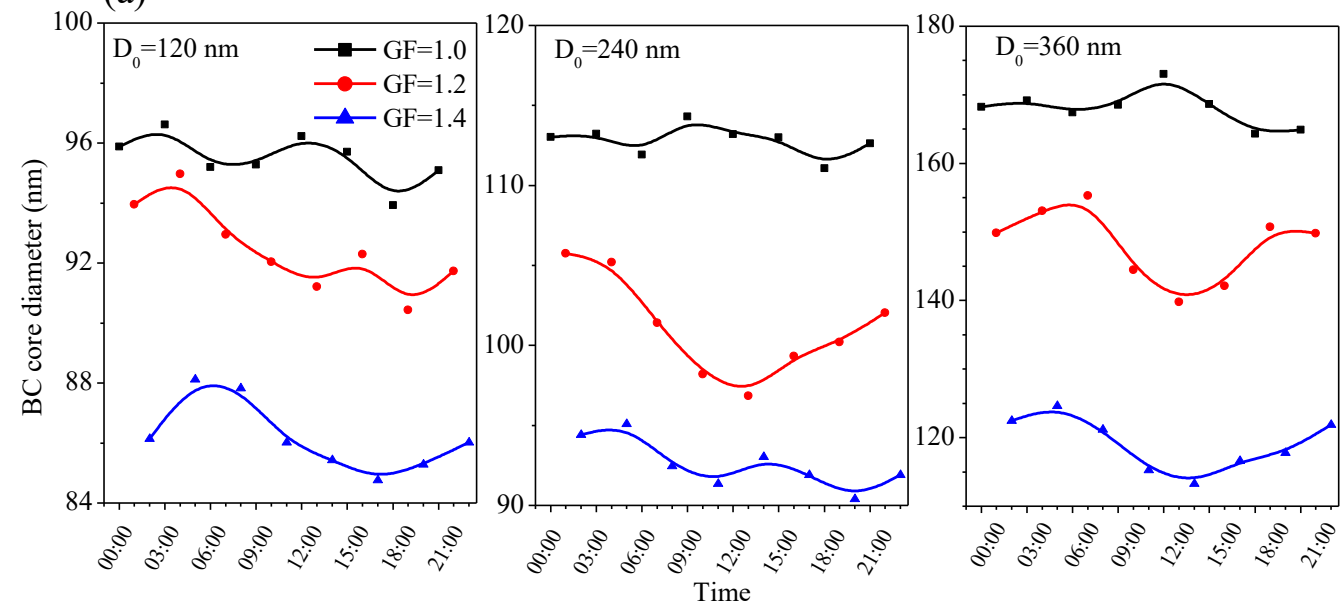

(b)
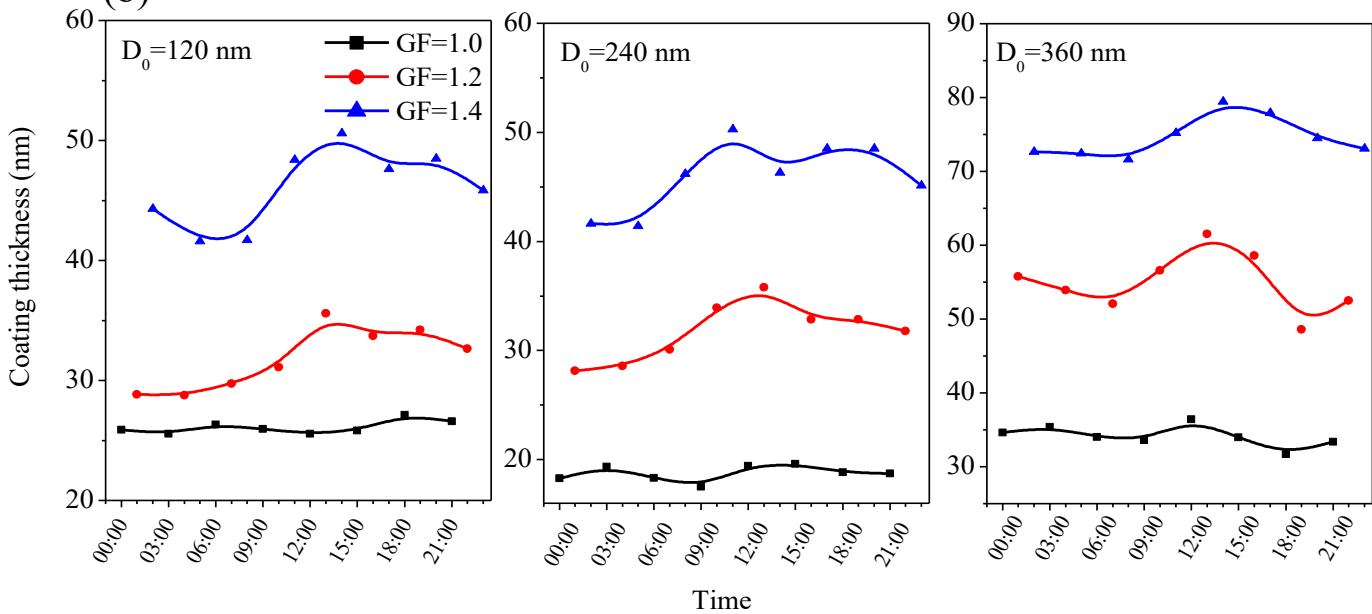

Figure 5. Diurnal variations in $\mathrm{rBC}$ (a) core size and (b) coating thickness at different GFs.

It is interesting to note that the core sizes for the hygroscopic-mode $\mathrm{BC}$ particles increased during nighttime (21:00 to 06:00 LT), while coating thickness decreased (since the entire electron mobility diameter was fixed). This observation suggests that the coating material on BC particles might be different between daytime and nighttime. To achieve the same GF, an increased coating thickness is required for less hygroscopic coating materials, as the hygroscopicity of a $\mathrm{rBC}$ core is always constant $(\mathrm{GF}=1.0)$.

In this study, the main uncertainty associated with the HTDMA-measured GF of soot particles was influenced by particle morphology. For fresh BC particles with an aggregate structure, the mobility diameter $\left(D_{\mathrm{mob}}\right)$ measured by a DMA is normally larger than its geometric volume / mass equivalent diameter $\left(D_{\mathrm{ve}}\right)$ (DeCarlo et al., 2004). However, coating on soot aggregates can modify its morphology (Weingartner et al., 1997; Lewis et al., 2009; Pagels et al., 2009) by making soot aggregate more compact. Change of particle morphology affects $D_{\text {mob }}$ measurement. It has been reported that more compact $\mathrm{BC}$ particles tend to exhibit smaller mobility diameter and higher effective density (Zhang et al., 2008; Pagels et al., 2009). In HTDMA measurements, if BC-containing particles' shape is significantly fractal, the water adsorption process in HTDMA would likely make them more compact, and therefore their GFs soot particles would be underestimated. These effects are less pronounced for particles that are less fractal. Due to the limitation of HTDMA, the complex morphology or $\rho_{\mathrm{BC}}$ of BC-containing particles cannot be explicitly determined in this study. Thus, a conventional core-shell model for a BCcontaining particle has to be assumed. The $\mathrm{GF}=1.0$ results show average coating thicknesses of $\sim 20-35 \mathrm{~nm}$, suggesting the presence of non-BC materials or the effect of a nonspherical shape on size measurement. 


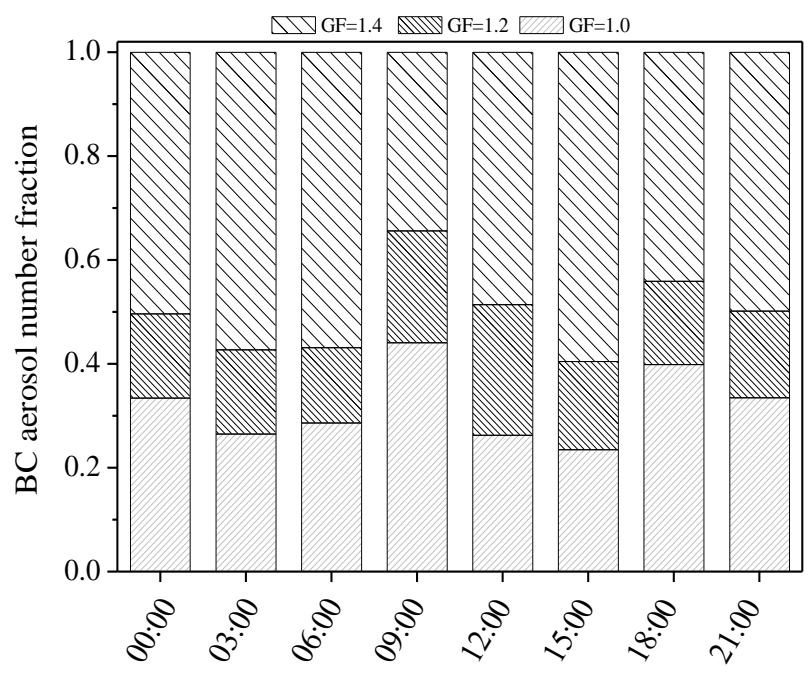

Figure 6. Diurnal variations in the GF distribution for BC particles. The BC aerosol number fraction for each $\mathrm{GF}$ is defined as (BC aerosol number concentration for this GF) / (sum of BC aerosol number concentration for $\mathrm{GF}=1.0,1.2$, and 1.4).

\subsubsection{Diurnal variations in the distribution of $\mathrm{BC}$ particle growth factors}

Fresh BC particles usually have a low GF. Through aging processes, the GF of $\mathrm{BC}$ particles increases. It would be interesting to see how the GF distributions of $\mathrm{BC}$ particles change during the day and obtain a rough estimate of how fast the aging process occurred. Figure 6 shows the diurnal variations in the distribution of $\mathrm{BC}$ particle growth factors. Note only three GFs were measured by the HTDMA-SP2 system. Here, the $\mathrm{BC}$ aerosol number fraction for each GF is defined as (BC aerosol number concentration for this GF) / (sum of $\mathrm{BC}$ aerosol number concentration for $\mathrm{GF}=1.0,1.2$, and 1.4). It is found that the $\mathrm{BC}$ aerosol number fraction for $\mathrm{GF}=1.0$ reached two maxima at around 09:00 and 18:00 LT, probably due to rush hour traffic. Only $3 \mathrm{~h}$ after 09:00 or 18:00 LT, the $\mathrm{BC}$ aerosol number fractions for $\mathrm{GF}=1.0$ dropped significantly (from 0.44 to 0.26 and from 0.40 to 0.36 , respectively). Meanwhile, the $\mathrm{BC}$ aerosol number fractions for $\mathrm{GF}=1.4$ increased (from 0.34 at 09:00 LT to 0.49 at 12:00 LT and from 0.44 at 18:00 LT to 0.50 at 21:00 LT). Evidently, the GF distribution of BC particles changed rapidly even in just $3 \mathrm{~h}$. This change was probably due to $\mathrm{BC}$ particle aging, and the aging timescale is around several hours.

The coating thickness of $\mathrm{BC}$ particles from this study (20 $\sim 80 \mathrm{~nm}$ for BC particles with an electrical mobility diameter of $120-360 \mathrm{~nm}$ ) was in the range of previous measurements from other cities. For example, Laborde et al., measured BC coating thickness in Paris during wintertime (Laborde et al., 2013). They found coating thickness was approximately $33 \mathrm{~nm}$ on average for a rBC core size from 180 to $280 \mathrm{~nm}$. Liu et al. report an average coating thickness of $\sim 40 \mathrm{~nm}$ for
Table 1. Number counts and fractions of the five types of BCcontaining particles detected by the SPAMS.

\begin{tabular}{lrr}
\hline Type & $\begin{array}{r}\text { Number count } \\
\text { of particles }\end{array}$ & $\begin{array}{r}\text { Fraction of } \\
\text { particles }\end{array}$ \\
\hline Pure EC & 5191 & $8.1 \%$ \\
KEC & 21456 & $33.3 \%$ \\
NaKEC & 11001 & $17.1 \%$ \\
ECOC & 21225 & $33.0 \%$ \\
Others & 5495 & $8.5 \%$ \\
\hline Total BC-containing & 64368 & $100 \%$ \\
particles & & \\
\hline
\end{tabular}

$\mathrm{BC}$ particles with an electrical mobility diameter of $163 \mathrm{~nm}$ (Liu et al., 2013). A field study in London during wintertime shows that the average coating thickness for BC particles 137,143 , and $169 \mathrm{~nm}$ in diameter were $\sim 15,22$, and $33 \mathrm{~nm}$, respectively (Liu et al., 2014).

The rapid change in $\mathrm{BC}$ particle coating thickness suggests that the aging timescale was around several hours. This timescale is consistent with a previous modeling study (Riemer et al., 2004).

\subsection{BC-containing particle types identified by SPAMS}

The mixing state and aging degree of BC-containing particles have been studied using a SPAMS. Noticeably, the particle size range for the SPAMS is from 200 to $2000 \mathrm{~nm}$. The detection efficiency drops rapidly below $400 \mathrm{~nm}$ and above $1200 \mathrm{~nm}$ (Li et al., 2011). However, most pure BC particles are smaller than $200 \mathrm{~nm}$ (Kondo et al., 2006), which is close to the lower size limit for the SPAMS and can only be detected at a low efficiency. Based on SPAMS mass spectra patterns, BC particles were classified into five types: EC, NaKEC (sodium- and potassium-rich EC), ECOC (EC and OC), KEC (potassium-rich EC), and others. Their relative contributions are shown in Table 1. The average mass spectra for each particle type are shown in Fig. S2 in the Supplement.

Pure EC particles only presented $\mathrm{BC}$ fragment ions $\left(\mathrm{C}_{n}^{+}\right.$ and $\mathrm{C}_{n}^{-}$) in both positive and negative ion mass spectra. There were low signals of secondary species, such as sulfate or nitrate, indicating that pure EC had not gone through significant aging in the atmosphere; thus the EC type was made up of freshly emitted BC particles.

NaKEC particles exhibited strong signals for BC fragment ions in both positive and negative mass spectra, additionally potassium $\left({ }^{+39} \mathrm{~K}^{+}\right)$and sodium $\left({ }^{+23} \mathrm{Na}^{+}\right)$in positive ion mass spectra, and nitrate ${ }^{-46} \mathrm{NO}_{2}^{-}$and $\left.{ }^{-62} \mathrm{NO}_{3}^{-}\right)$and sulfate $\left({ }^{-97} \mathrm{HSO}_{4}^{-}\right)$in the negative ion mass spectra. Hydrocarbonlike organic aerosol (HOA) is dominated by alkyl fragment signatures as well as the $\mathrm{C}_{n} \mathrm{H}_{2 n+1}^{+}(m / z=29,43,57)$ and $\mathrm{C}_{n} \mathrm{H}_{2 n-1}^{+}(m / z=27,41,55)$ ions. The time series of HOA correlated well with those of $\mathrm{NO}_{2}$ and $\mathrm{CO}$, two tracers of 
vehicle emissions (Fig. S3a in the Supplement). The diurnal pattern of HOA ion intensity further suggests the association of HOA with traffic activities, as it showed two obvious peaks during the morning and evening rush hours ( $\mathrm{Li}$ et al., 2017). HOA as a tracer of traffic emission correlated reasonably well with the NaKEC particle numbers $\left(R^{2}=0.560\right)$, as shown in Fig. S3b in the Supplement.

The ECOC particles internally mixed with many $\mathrm{OC}$ signals, including ${ }^{+37} \mathrm{C}_{3} \mathrm{H},{ }^{+43} \mathrm{CH}_{3} \mathrm{CO}^{+},{ }^{+50} \mathrm{C}_{4} \mathrm{H}_{2}^{+},{ }^{+51} \mathrm{C}_{4} \mathrm{H}^{+}$, ${ }^{+61} \mathrm{CH}_{3} \mathrm{C}(\mathrm{OH})=\mathrm{OH}^{+},{ }^{+62}\left(\mathrm{CH}_{3}\right)_{2} \mathrm{NHOH}^{+}$, and ${ }^{+23} \mathrm{Na}^{+}$ and $\mathrm{BC}$ fragment ions $\left(\mathrm{C}_{n}^{+}\right)$. The presence of a high signal intensity for sulfate $\left({ }^{-97} \mathrm{HSO}_{4}^{-}\right)$and a relatively low signal intensity for nitrate $\left({ }^{-46} \mathrm{NO}_{2}^{-},{ }^{-62} \mathrm{NO}_{3}^{-}\right)$suggests that they were aged $\mathrm{BC}$ particles. $\mathrm{BC}$ particles with various intensities of OC, nitrate, and sulfate were commonly detected in ambient measurements with an ATOFMS (Moffet et al., 2008; Ault et al., 2009; Dall'Osto and Harrison, 2006) and were also attributed to aged traffic emissions (Healy et al., 2012).

KEC particles were characterized by an intense ${ }^{+39} \mathrm{~K}^{+}$ signal in the positive ion mass spectra and strong signals for ${ }^{-26} \mathrm{CN}^{-}$and ${ }^{-42} \mathrm{CNO}^{-}$in the negative ion mass spectra. Significant intensities of ion fragments of levoglucosan, such as ${ }^{-71} \mathrm{C}_{3} \mathrm{H}_{3} \mathrm{O}_{2}^{-}$and ${ }^{-73} \mathrm{C}_{3} \mathrm{H}_{5} \mathrm{O}_{2}^{-}$, were also observed. Typical $\mathrm{BC}$ fragments $\mathrm{C}_{n}^{-}$appeared in the negative ion mass spectra. Similar to ECOC, the presence of a high signal intensity of ${ }^{-97} \mathrm{HSO}_{4}^{-},{ }^{-46} \mathrm{NO}_{2}^{-}$, and ${ }^{-62} \mathrm{NO}_{3}^{-}$signals indicates significant particle aging in the atmosphere (Leskinen et al., 2007; Reid et al., 2005). These characteristics suggest that their sources are BB or coal combustion or both (Andreae, 1983; Soto-Garcia et al., 2011; Wang et al., 2013; Gong et al., 2016). Particles with similar mass spectral patterns previously observed in several urban field studies were also assigned to the sources of combustion of biomass or coal (Moffet et al., 2008; Healy et al., 2012; Bi et al., 2011; Wang et al., 2013; Gong et al., 2016).

The others particle type was not grouped to any of the previous four types and it accounts for only $8.5 \%$ in total BC particle number concentration. The average mass spectrum of this particle type is displayed in Fig. S2e in the Supplement. However, this is not the focus of this study.

The relative fractions of aerosol types as a function of particle size were plotted in Fig. S4 in the Supplement. Generally, the number fraction for each particle type is highly dependent on particle size. Sharp changes in BC particle mixing states have been found between the size ranges of 200-400 nm and 400-800 nm. EC and NaKEC are the major fraction types in the $200-400 \mathrm{~nm}$ size range. In contrast, the larger size range (400-800 nm) was dominated by ECOC and KEC types. For convenience of discussion, we separated particles into two groups based on their $d_{\mathrm{va}}$, namely $\mathrm{G}_{200-400}\left(200 \mathrm{~nm}<d_{\mathrm{va}}<400 \mathrm{~nm}\right)$ and $\mathrm{G}_{400-800}$ $\left(400 \mathrm{~nm}<d_{\mathrm{va}}<800 \mathrm{~nm}\right)$. In this work, $d_{\mathrm{va}}=150 \mathrm{~nm}$ $\left(d_{\mathrm{m}}=120 \mathrm{~nm}\right)$ was out of the SPAMS detection range, while $d_{\mathrm{va}}=312 \mathrm{~nm} \quad\left(d_{\mathrm{m}}=240 \mathrm{~nm}\right) \quad$ and $\quad d_{\mathrm{va}}=468 \mathrm{~nm}$

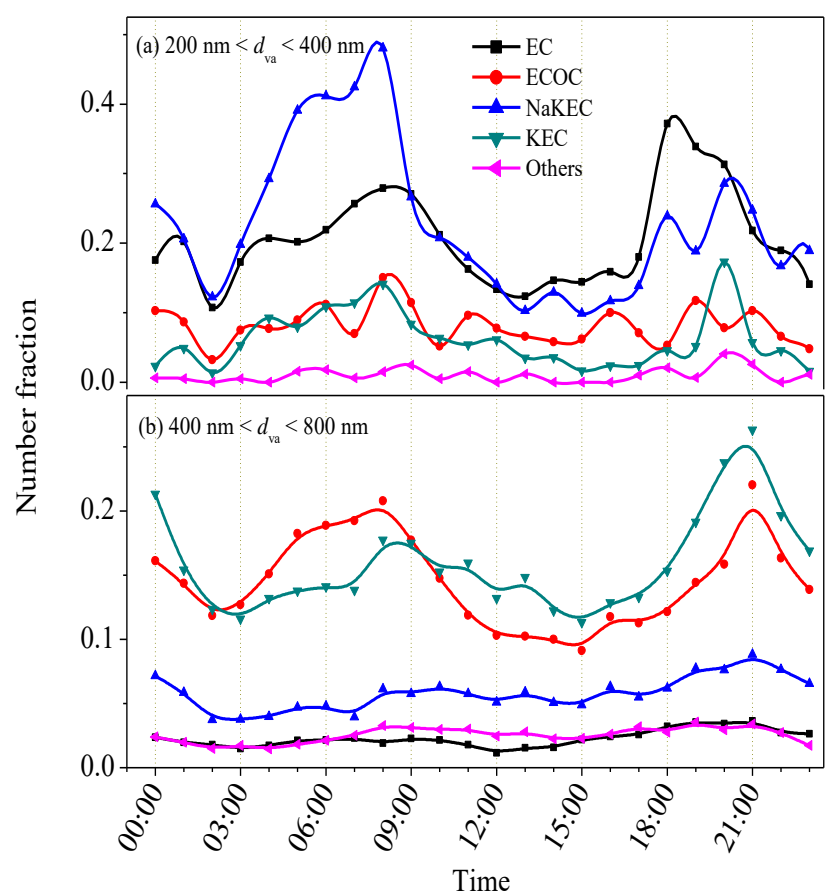

Figure 7. Diurnal variations in number fraction of each classified particle type: (a) $\mathrm{G}_{200-400}: 200<d_{\mathrm{va}}<400 \mathrm{~nm}$ and (b) $\mathrm{G}_{400-800}$ : $400<d_{\mathrm{va}}<800 \mathrm{~nm}$.

$\left(d_{\mathrm{m}}=360 \mathrm{~nm}\right)$ fell in the range of $\mathrm{G}_{200-400}$ and $\mathrm{G}_{400-800}$, respectively.

The diurnal variations in number fraction of each particle type in $\mathrm{G}_{200-400}$ were calculated and shown in Fig. 7a. It is found that number fraction of the EC and NaKEC types displayed pronounced diurnal patterns with two major peaks in the early morning (06:00-09:00 LT) and in the evening (18:00-21:00 LT), possibly relating to traffic. From the hygroscopicity measurement $\left(D_{0}=240\right.$ and $360 \mathrm{~nm}$ in Fig. $\left.4 \mathrm{a}\right)$, the elevated $\mathrm{BC}$ particle number concentration at $\mathrm{GF}=1.0$ during these two time frames suggests that the elevated concentrations of hydrophobic BC particle aerosol were probably associated with EC and NaKEC types, which are produced from traffic sources.

A different pattern has been observed for $\mathrm{G}_{400-800}$ (shown in Fig. 7b). The ECOC and KEC types accounted for the major number fractions in the $400 \mathrm{~nm} \sim 800 \mathrm{~nm}$ range. The diurnal variations in these two particle types share a similar trend, while the other two types (EC and NaKEC) showed no significant variation. The EC and NaKEC types only attributed to small proportions of $\mathrm{G}_{400-800}$ particles. Interestingly, the number fraction of ECOC in $\mathrm{G}_{400-800}$ also showed two major peaks in the morning and evening, suggesting that ECOC was aged $\mathrm{BC}$ particles from traffic emissions. The KEC peak in the evening was much more pronounced than that in the morning, and this might be due to BB, which is still widely used for domestic cooking (in the evening) in the countryside 

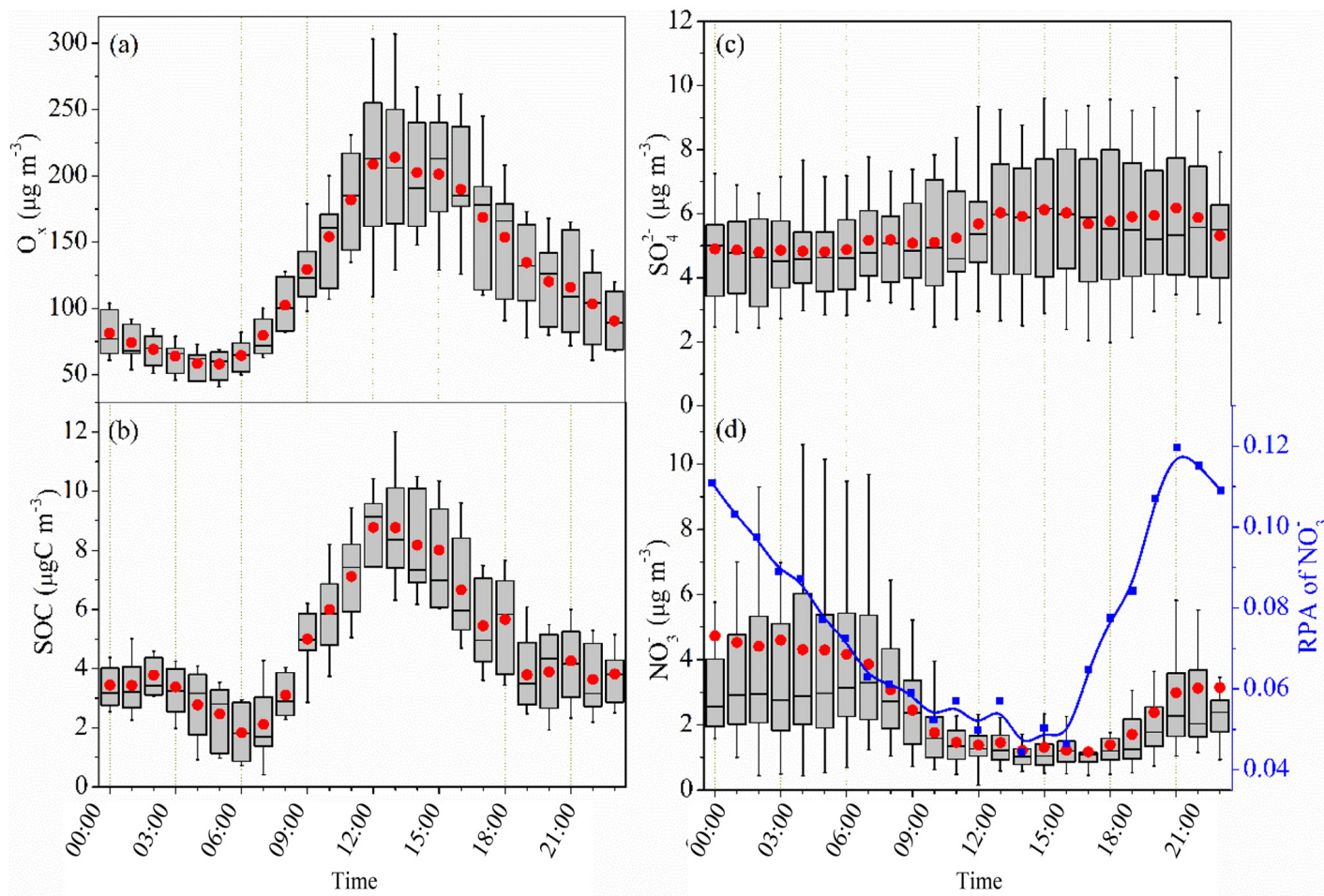

Figure 8. Averaged diurnal variations in $\mathrm{O}_{x}, \mathrm{SOC}, \mathrm{SO}_{4}^{2-}$, and $\mathrm{NO}_{3}^{-}$mass concentration in (a), (b), (c), and (d), respectively. The blue line in (d) is daily variation in relative peak area of $\mathrm{NO}_{3}^{-}$measured by SPAMS.

around Shanghai. These BB aerosols were then transported to the sampling site.

\subsection{The relations between the mixing state and hygroscopicity of BC particles}

To elucidate the relation between mixing state and hygroscopicity of $\mathrm{BC}$ particles, the detailed chemical composition and mixing state information from the EC / OC, MARGA, and SPAMS was compared to the HTDMA-SP2 hygroscopicity measurements. As discussed in Sect. 3.1, we found that the rBC core sizes for the hygroscopic-mode particles increased during nighttime (21:00-06:00 LT) while coating thickness decreased, indicating the $\mathrm{BC}$ particle coating compositions were different between daytime and nighttime. The major secondary aerosol coating materials in the polluted boundary layer could be SOC, sulfate, and nitrate. Therefore, the diurnal trends in these species have been investigated and compared to BC particles' hygroscopicity.

\subsubsection{Major secondary ionic species}

The dominant ionic species in urban aerosols in Shanghai are sulfate, nitrate, and ammonium (Ye et al., 2013). To study the chemical composition dependence on hygroscopicity, mass concentrations of $\mathrm{SO}_{4}^{2-}, \mathrm{NO}_{3}^{-}$, and $\mathrm{NH}_{4}^{+}$were measured us- ing a MARGA during this field study. As shown in Fig. 8c, the average sulfate concentration varied in a small range from $\sim 4.8$ to $6.1 \mu \mathrm{g} \mathrm{m}^{-3}$. Its concentration in the daytime was only slightly higher than that of nighttime. The average mass concentration of $\mathrm{NO}_{3}^{-}$varied between $1.1 \mu \mathrm{g} \mathrm{m}^{-3}$ and $4.4 \mu \mathrm{g} \mathrm{m}^{-3}$ with an average of $2.3 \mu \mathrm{g} \mathrm{m}^{-3}$. Similar to our previous study (Wang et al., 2016a), the nitrate concentrations at night were clearly elevated (Fig. 8d). The relative peak area (RPA) of $\mathrm{NO}_{3}^{-}$in $\mathrm{BC}$ particles measured by SPAMS is also consistent with the MARGA measurement (Fig. 8d). During the nighttime in summer, lower temperature, higher $\mathrm{RH}$, and a high concentration of $\mathrm{NO}_{3}\left(\mathrm{~N}_{2} \mathrm{O}_{5}\right)$ favor the formation of nitrate in the particle phase (Wang et al., 2009, 2016a).

\subsubsection{Elevated SOC concentrations in the daytime}

Photochemical reactions are a major formation pathway of SOC (Kroll and Seinfeld, 2008; Zhang et al., 2018). Odd oxygen $\left(\mathrm{O}_{x}=\mathrm{O}_{3}+\mathrm{NO}_{2}\right)$ was often used as an indicator of photochemical oxidant concentration in the atmosphere (Herndon et al., 2008; Hu et al., 2016; Wood et al., 2010). The diurnal variations in $\mathrm{SOC}$ and $\mathrm{O}_{x}$ mass concentrations at a $1 \mathrm{~h}$ resolution were plotted in Fig. 8. In this work, average SOC and $\mathrm{O}_{x}$ varied between 1.8 and $8.8 \mu \mathrm{gC} \mathrm{m}{ }^{-3}$ and 58 and $214 \mu \mathrm{g} \mathrm{m}^{-3}$, respectively. The correlation coefficient 


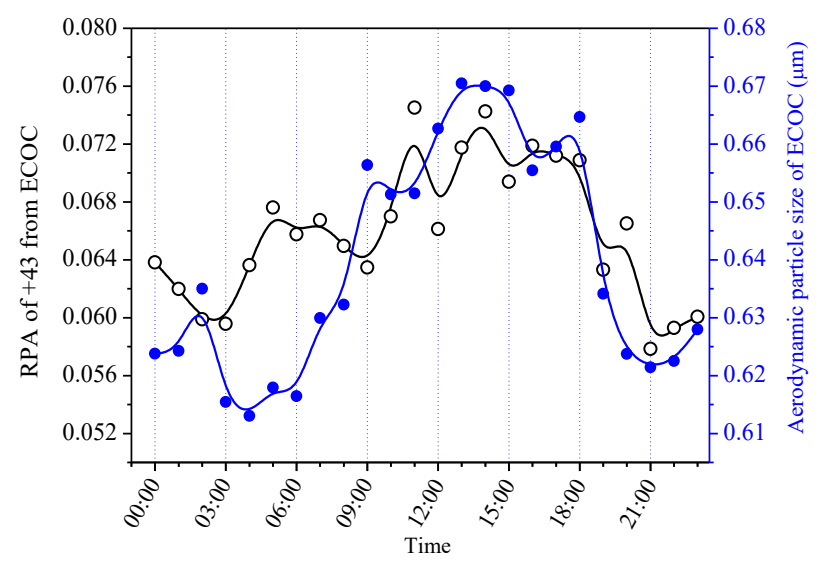

Figure 9. Diurnal variations in relative peak area (RPA) of $m / z+43$ from ECOC particles and the average aerodynamic particle size of ECOC particles.

$(R)$ between SOC and $\mathrm{O}_{x}$ was 0.772 (shown in Fig. S5 in the Supplement), indicating that the SOC formation was associated with the photochemical oxidant concentration during this study.

Single-particle mass spectrometry was also used to further investigate the mixing state and possible formation pathways of SOC. The RPA of $+43\left[\mathrm{CH}_{3} \mathrm{CO}^{+} / \mathrm{CHNO}^{+}\right]$during the daytime is a tracer of SOC formation (Qin et al., 2012; Zhang et al., 2014, 2018). Time series of hourly-averaged RPAs of $m / z+43$ in ECOC particles was shown in Fig. 9. Overall, the $m / z+43$ curve peaked in the afternoon, which was consistent with the trend in $\mathrm{O}_{x}$. This result indicates that SOC $(m / z=+43)$ produced by photochemical reactions condensed on BC particles. The average ECOC particle size versus time is also shown in Fig. 9. It peaked between 13:00 to 15:00 LT in the afternoon. Since the concentration of sulfate in the daytime was only slightly higher than that in nighttime (Fig. 8c), the increase in ECOC particle size was mainly caused by the condensation of SOC rather than secondary inorganic species. Therefore, in the afternoon, the intense photochemical process resulted in $\mathrm{BC}$ particles coated with more organic materials, leading to an increased coating thickness.

\subsubsection{Hygroscopicity and mixing state (coating material)}

As discussed above, the chemical composition measurement clearly shows BC particles were coated with more SOC in the daytime and with more nitrate in the nighttime. Sulfate concentration did not change much between daytime and nighttime. Meanwhile, at a given GF, the coating for hygroscopicmode BC particles was thicker in the daytime and thinner in the nighttime. The water uptake ability of nitrate is much stronger than secondary organics. Thus, compared to SOC, less nitrate coating is needed for a given hygroscopicity or GF.
To better understand this finding, we estimated volumes of different coating materials required for a $\mathrm{BC}$ particle with a given hygroscopicity using the Zdanovskii-StokesRobinson (ZSR) mixing rule (Stokes and Robinson, 1966),

$\mathrm{GF}_{\mathrm{ZSR}}\left(\mathrm{RH}, D_{\mathrm{p}}\right)=\left(\sum_{i} \mathrm{GF}_{i}\left(\mathrm{RH}, D_{\mathrm{p}}\right)^{3} \varepsilon_{i}\right)^{1 / 3}$.

The $\varepsilon_{i}$ is the volume fraction of $\mathrm{rBC}$, nitrate, sulfate, or organic coating in $\mathrm{BC}$ particles. For simplicity, we assume rBC is covered by a mixture containing either SOC / $\left(\mathrm{NH}_{4}\right)_{2} \mathrm{SO}_{4}$ or $\left(\mathrm{NH}_{4}\right)_{2} \mathrm{SO}_{4} / \mathrm{NH}_{4} \mathrm{NO}_{3}$, representing the mixing state of $\mathrm{BC}$ in daytime and nighttime, respectively. The GF for SOC is set to be 1.2 since Sjogren et al. reported a uniform growth factor $\mathrm{GF}_{\mathrm{SOA}}=1.2(\mathrm{RH}=90 \%)$ according to the ZSR modeling results and field measurements (Sjogren et al., 2008). This value is at the high end of a previously measured SOA hygroscopicity range, thereby representing highly aged and oxidized SOA (Varutbangkul et al., 2006; Baltensperger et al., 2005). The GFs of pure $\mathrm{BC},\left(\mathrm{NH}_{4}\right)_{2} \mathrm{SO}_{4}$, and $\mathrm{NH}_{4} \mathrm{NO}_{3}$ aerosol with a dry size of $163 \mathrm{~nm}$ at $\mathrm{RH}=90 \%$ are calculated using the Aerosol Diameter-Dependent Equilibrium Model (ADDEM) model. Their values are 1.0, 1.7, and 1.8, respectively (Topping et al., 2005a, b).

For a coated BC particle with a dry diameter of $163 \mathrm{~nm}$ and a GF of 1.4, the following relations would hold for a SOC / $\left(\mathrm{NH}_{4}\right)_{2} \mathrm{SO}_{4}$ coating (Eq. 3) and $\left(\mathrm{NH}_{4}\right)_{2} \mathrm{SO}_{4} / \mathrm{NH}_{4} \mathrm{NO}_{3}$ coating (Eq. 4).

$1.4=$

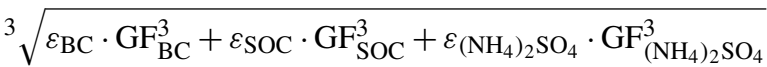
$1.4=$

$\sqrt[3]{\varepsilon_{\mathrm{BC}}^{\prime} \cdot \mathrm{GF}_{\mathrm{BC}}^{3}+\varepsilon_{\mathrm{NH}_{4} \mathrm{NO}_{3}} \cdot \mathrm{GF}_{\mathrm{NH}_{4} \mathrm{NO}_{3}}^{3}+\varepsilon_{\left(\mathrm{NH}_{4}\right)_{2} \mathrm{SO}_{4}} \cdot \mathrm{GF}_{\left(\mathrm{NH}_{4}\right)_{2} \mathrm{SO}_{4}}^{3}}$

$\varepsilon_{\mathrm{BC}}$ and $\varepsilon_{\mathrm{BC}}^{\prime}$, representing the volume fractions of the $\mathrm{rBC}$ core in two mixing states, are given by $\varepsilon_{\mathrm{BC}}=1-\varepsilon_{\mathrm{SOC}}-$

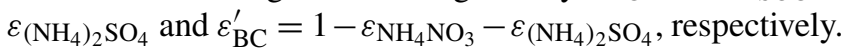

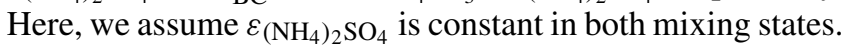

Combining the equations above, the ratio of volume fraction of $\mathrm{SOC}$ to $\mathrm{NH}_{4} \mathrm{NO}_{3}$ is

$\frac{\varepsilon \mathrm{SOC}}{\varepsilon_{\mathrm{NH}_{4} \mathrm{NO}_{3}}}=6.6$.

This calculation shows that a higher volume fraction of $\mathrm{SOC} /\left(\mathrm{NH}_{4}\right)_{2} \mathrm{SO}_{4}$ is needed for a BC particle to achieve the same $\mathrm{GF}$ as the one covered by $\left(\mathrm{NH}_{4}\right)_{2} \mathrm{SO}_{4} / \mathrm{NH}_{4} \mathrm{NO}_{3}$.

This result confirms that different atmospheric aging pathways lead to changes in aerosol mixing state with distinct hygroscopicities: during nighttime with low temperature and high $\mathrm{RH}$, formation or condensation of nitrates on $\mathrm{BC}$ particles enhanced the hygroscopicity of $\mathrm{BC}$ particles and resulted in the thinner coating of $\mathrm{BC}$ particles in the hygroscopic mode for each selected size. During daytime, condensation of photochemically generated SOC on BC particles 

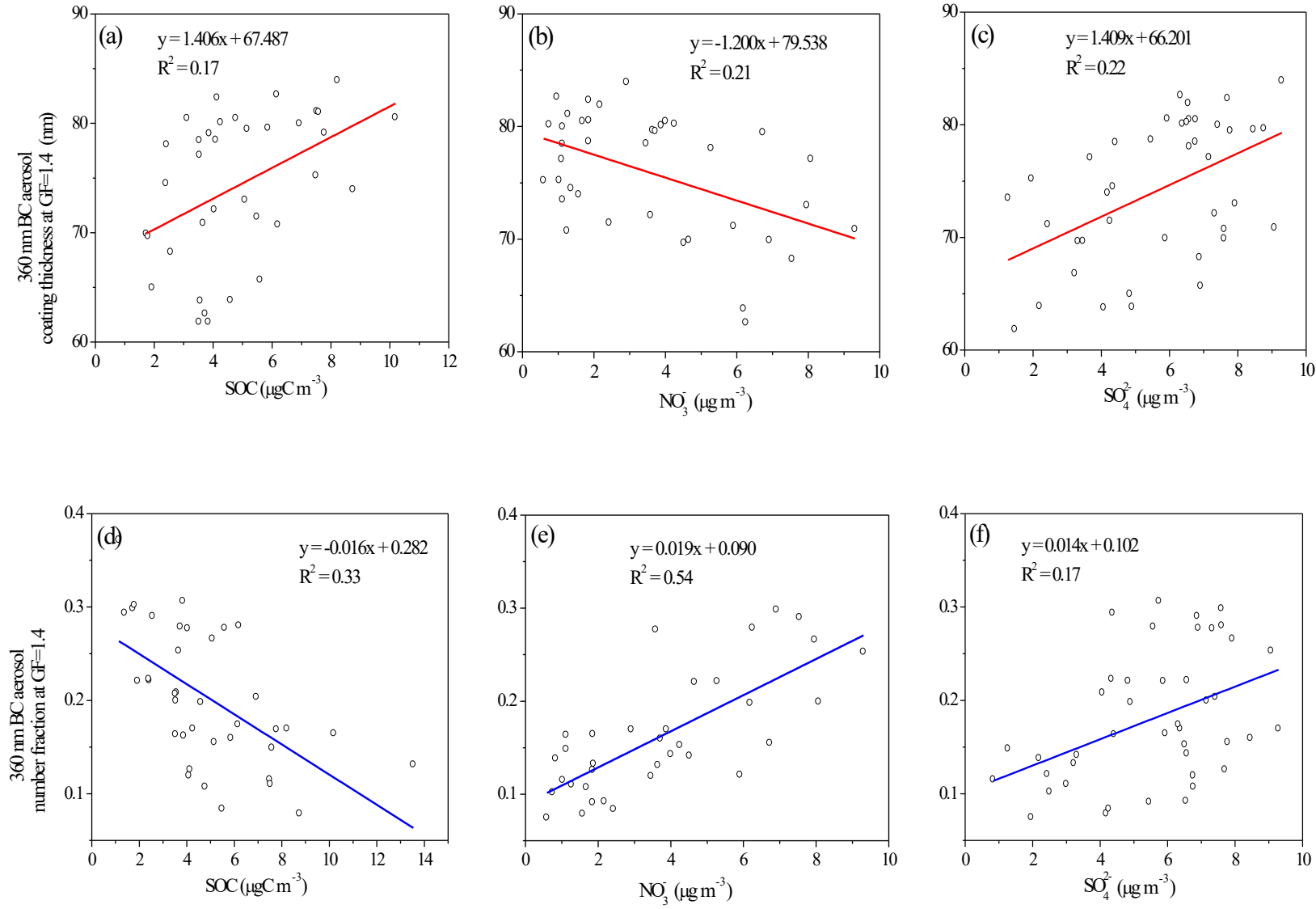

Figure 10. Relations between the coating thickness of $360 \mathrm{~nm}$ for BC particles with a GF of 1.4 and the concentration of (a) SOC, (b) nitrate, and (c) sulfate; relations between the number fraction of BC particles in $360 \mathrm{~nm}$ aerosol with a GF of 1.4 and the concentration of (d) SOC, (e) nitrate, and (f) sulfate.

was associated with the thicker coating of BC particles with less enhancement of hygroscopicity. The sulfate coating can enhance hygroscopicity of BC particles. However, unlike nitrate and SOC, its formation did not show a significant difference between day and night. This finding is consistent with our previous measurement of secondary species formation in Shanghai during the summertime. Shanghai is a typical Chinese megacity with heavy air pollution. In summer, high $\mathrm{NO}_{x}$ emission and ozone concentration lead to enhanced nitrate formation via the $\mathrm{N}_{2} \mathrm{O}_{5}$ pathway during nighttime (Wang et al., 2009; Pathak et al., 2009). Secondary organic aerosol and particulate sulfate are usually formed through photooxidation of organic vapor and $\mathrm{SO}_{2}$ during daytime (Kroll and Seinfeld, 2008; Wang et al., 2016). The differences in aging pathways between daytime and nighttime result in different coating materials and thickness on rBC cores, which can further impact their hygroscopicity. Noticeably, Liu et al. report that the hygroscopicity of $\mathrm{BC}$ particles was largely driven by the coating of ammonium nitrate (Liu et al., 2013). However, this may not be the case in Shanghai during summertime, as most particulate ammonium in Shanghai has been found to be in the form of ammonium sulfate (Wang et al., 2009; Pathak et al., 2009). Indeed, our SPAMS spectra for $\mathrm{BC}$ particles do not show the presence of large ammonium peaks (Fig. S2 in the Supplement) because most ammonium was in the form of ammonium sulfate, which is difficult to be ionized and detected in SPAMS (Wang et al., 2009).

Figure 10a-c compare the coating thickness of $360 \mathrm{~nm} \mathrm{BC}$ particles $(\mathrm{GF}=1.4)$ with other chemical indicators, such as SOC, nitrate, and sulfate. It shows that there was a positive correlation between the coating thickness and the SOC concentration and a negative correlation between the coating thickness and the nitrate concentration, which is consistent with their diurnal trends. There was a positive correlation between the coating thickness and sulfate concentration. Figure $5 \mathrm{~b}$ shows the coating thickness for $360 \mathrm{~nm}$ BC particles whose $\mathrm{GF}=1.4$ peaked in the afternoon. Formation of sulfate was also slightly enhanced during the afternoon due to stronger solar irradiation, resulting in this correlation.

Figure 10d-f show the number fraction of BC particles in $360 \mathrm{~nm}$ aerosol with a GF of 1.4 versus the concentrations of SOC, nitrate, and sulfate. It is found that the SOC had a negative correlation with the number fraction of $\mathrm{BC}$ particles in $360 \mathrm{~nm}$ aerosol with a GF of 1.4, while nitrate and 
sulfate had a positive correlation with the number fraction. This finding is consistent with the fact that SOC has a lower GF than nitrate and sulfate salts. When more SOC is formed and more likely covers BC particles' surfaces, fewer BC particles' GFs can reach 1.4. In contrast, when more nitrate or sulfate is formed and condenses on BC particles, more BC particles' GFs can reach 1.4.

\section{Conclusions}

In this study, a HTDMA-SP2 system along with SPAMS were used to measure BC particles' hygroscopic properties in Shanghai during the summer of 2017. Three hygroscopic modes, namely the hydrophobic mode, transition mode, and hydrophilic mode with GFs at 1.0, 1.2, and 1.4, respectively, were selected to study the diurnal variations in $\mathrm{rBC}$ core and coating thickness as a function of time.

Our results reveal that the hygroscopicity of BC particles is determined by the coating layer thickness and materials, both of which are affected by atmospheric aging processes. For a specific $\mathrm{BC}$ particle size, a thin coating layer corresponded to freshly emitted BC particles with low hygroscopicity (e.g., $\mathrm{GF}=1.0$ ). When $\mathrm{BC}$ particles became more hygroscopic (i.e., GF increases), the coating thickness increased. A high yield of particulate nitrate during nighttime was observed, and the nitrate coating greatly enhanced the hygroscopicity of BC particles. During daytime, strong SOC formation from photochemical oxidation played an important role in the evolution of the $\mathrm{BC}$ mixing state. A thinner layer of nitrate coating could convert fresh $\mathrm{BC}$ particles to aged hygroscopic ones while a thicker coating layer of SOC and sulfate was required to reach the same overall hygroscopicity.

This study shows that atmospheric aging processes in a polluted city area play critical roles in the fast change of aerosol mixing state during summertime. Time-resolved information on particle hygroscopicity is necessary to evaluate the aging process, wet removal, and climate effects of $\mathrm{BC}$ aerosols.

Data availability. Raw and processed data are available upon request to the authors.

\section{The Supplement related to this article is available online at: https://doi.org/10.5194/acp-18-15201-2018- supplement}

Author contributions. KL performed the experiment and analyzed the data. XYe, HP, XL and HC help set up the measurement system and performed the experiment. XYa and XW designed the study. JC and YC provided ECOC and MARGA data. All authors contributed to writing the paper.
Competing interests. The authors declare that they have no conflict of interest.

Acknowledgements. This work was supported by the National Natural Science Foundation of China (nos. 91544224, 41775150, 41827804, 21507010).

Edited by: Markus Petters

Reviewed by: two anonymous referees

\section{References}

Allen, G. A., Lawrence, J., and Koutrakis, P.: Field validation of a semi-continuous method for aerosol black carbon (aethalometer) and temporal patterns of summertime hourly black carbon measurements in southwestern PA, Atmos. Environ., 33, 817-823, https://doi.org/10.1016/S1352-2310(98)00142-3, 1999.

Andreae, M. O.: Soot carbon and excess fine potassium: Long-range transport of combustion-derived aerosols, Science, 220, 11481151, https://doi.org/10.1126/science.220.4602.1148, 1983.

Ault, A. P., Moore, M. J., Furutani, H., and Prather, K. A.: Impact of emissions from the Los Angeles port region on San Diego air quality during regional transport events, Environ. Sci. Technol., 43, 3500-3506, https://doi.org/10.1021/es8018918, 2009.

Baltensperger, U., Kalberer, M., Dommen, J., Paulsen, D., Alfarra, M. R., Coe, H., Fisseha, R., Gascho, A., Gysel, M., and Nyeki, S.: Secondary organic aerosols from anthropogenic and biogenic precursors, Faraday Discuss., 130, 265-278, https://doi.org/10.1039/b417367h, 2005.

Baumgardner, D., Kok, G., and Raga, G.: Warming of the Arctic lower stratosphere by light absorbing particles, Geophys. Res. Lett., 31, L06117, https://doi.org/10.1029/2003GL018883, 2004.

Bhugwant, C., Cachier, H., Bessafi, M., and Leveau, J.: Impact of traffic on black carbon aerosol concentration at la Reunion Island (Southern Indian Ocean), Atmos. Environ., 34, 3463-3473, https://doi.org/10.1016/S1352-2310(99)00405-7, 2000.

Bi, X., Zhang, G., Li, L., Wang, X., Li, M., Sheng, G., Fu, J., and Zhou, Z.: Mixing state of biomass burning particles by single particle aerosol mass spectrometer in the urban area of PRD, China, Atmos. Environ., 45, 3447-3453, https://doi.org/10.1016/j.atmosenv.2011.03.034, 2011.

Bond, T. C. and Bergstrom, R. W.: Light absorption by carbonaceous particles: An investigative review, Aerosol Sci. Tech., 40, 27-67, https://doi.org/10.1080/02786820500421521, 2006.

Bond, T. C., Doherty, S. J., Fahey, D., Forster, P., Berntsen, T., DeAngelo, B., Flanner, M., Ghan, S., Kärcher, B., and Koch, D.: Bounding the role of black carbon in the climate system: A scientific assessment, J. Geophys. Res.-Atmos., 118, 5380-5552, https://doi.org/10.1002/jgrd.50171, 2013.

Cao, J.-J., Zhu, C.-S., Tie, X.-X., Geng, F.-H., Xu, H.-M., Ho, S., Wang, G.-H., Han, Y.-M., and Ho, K.-F.: Characteristics and sources of carbonaceous aerosols from Shanghai, China, Atmos. Chem. Phys., 13, 803-817, https://doi.org/10.5194/acp-13-8032013, 2013.

Change, I. P. O. C.: Climate change 2014: mitigation of climate change, Cambridge University Press, Cambridge, UK, 114-150, 2015. 
Chen, J., Zhao, C., Ma, N., Liu, P., Göbel, T., Hallbauer, E., Deng, Z., Ran, L., Xu, W., and Liang, Z.: A parameterization of low visibilities for hazy days in the North China Plain, Atmos. Chem. Phys., 12, 4935-4950, https://doi.org/10.5194/acp12-4935-2012, 2012.

Chirico, R., DeCarlo, P., Heringa, M., Tritscher, T., Richter, R., Prévôt, A., Dommen, J., Weingartner, E., Wehrle, G., and Gysel, M.: Impact of aftertreatment devices on primary emissions and secondary organic aerosol formation potential from in-use diesel vehicles: results from smog chamber experiments, Atmos. Chem. Phys., 10, 11545-11563, https://doi.org/10.5194/acp-1011545-2010, 2010.

Chou, C.-K., Lee, C., Cheng, M., Yuan, C., Chen, S., Wu, Y., Hsu, W., Lung, S., Hsu, S., and Lin, C.: Seasonal variation and spatial distribution of carbonaceous aerosols in Taiwan, Atmos. Chem. Phys., 10, 9563-9578, https://doi.org/10.5194/acp10-9563-2010, 2010.

Dall'Osto, M. and Harrison, R. M.: Chemical characterisation of single airborne particles in Athens (Greece) by ATOFMS, Atmos. Environ., 40, 7614-7631, https://doi.org/10.1016/j.atmosenv.2006.06.053, 2006.

DeCarlo, P. F., Slowik, J. G., Worsnop, D. R., Davidovits, P., and Jimenez, J. L.: Particle morphology and density characterization by combined mobility and aerodynamic diameter measurements. Part 1: theory, Aerosol Sci. Technol., 38, 1185-1205, https://doi.org/10.1080/027868290903907, 2004.

Dreher, D. B. and Harley, R. A.: A fuel-based inventory for heavyduty diesel truck emissions, J. Air Waste Manage., 48, 352-358, https://doi.org/10.1080/10473289.1998.10463686, 1998.

Du, H., Kong, L., Cheng, T., Chen, J., Yang, X., Zhang, R., Han, Z., Yan, Z., and Ma, Y.: Insights into ammonium particleto-gas conversion: non-sulfate ammonium coupling with nitrate and chloride, Aerosol Air Qual. Res., 10, 589-595, https://doi.org/10.4209/aaqr.2010.04.0034, 2010.

Dusek, U., Reischl, G. P., and Hitzenberger, R.: CCN activation of pure and coated carbon black particles, Environ. Sci. Technol., 40, 1223-1230, https://doi.org/10.1021/es0503478, 2006.

Gao, R., Schwarz, J., Kelly, K., Fahey, D., Watts, L., Thompson, T., Spackman, J., Slowik, J., Cross, E., and Han, J. H.: A novel method for estimating light-scattering properties of soot aerosols using a modified singleparticle soot photometer, Aerosol Sci. Tech., 41, 125-135, https://doi.org/10.1080/02786820601118398, 2007.

Gong, X., Zhang, C., Chen, H., Nizkorodov, S. A., Chen, J., and Yang, X.: Size distribution and mixing state of black carbon particles during a heavy air pollution episode in Shanghai, Atmos. Chem. Phys., 16, 5399-5411, https://doi.org/10.5194/acp16-5399-2016, 2016.

Gysel, M., Nyeki, S., Weingartner, E., Baltensperger, U., Giebl, H., Hitzenberger, R., Petzold, A., and Wilson, C. W.: Properties of jet engine combustion particles during the PartEmis experiment: Hygroscopicity at subsaturated conditions, Geophys. Res. Lett., 30, 1566, https://doi.org/10.1029/2003GL016896, 2003.

Harris, S. J. and Maricq, M. M.: Signature size distributions for diesel and gasoline engine exhaust particulate matter, J. Aerosol Sci., 32, 749-764, https://doi.org/10.1016/S00218502(00)00111-7, 2001

Healy, R. M., Sciare, J., Poulain, L., Kamili, K., Merkel, M., Müller, T., Wiedensohler, A., Eckhardt, S., Stohl, A., and Sarda-Estève,
R.: Sources and mixing state of size-resolved elemental carbon particles in a European megacity: Paris, Atmos. Chem. Phys., 12, 1681-1700, https://doi.org/10.5194/acp-12-1681-2012, 2012.

Heintzenberg, J. and Covert, D. S.: On the distribution of physical and chemical particle properties in the atmospheric aerosol, J. Atmos. Chem., 10, 383-397, https://link.springer.com/article/10.1007/BF00115781, 1990.

Herich, H., Kammermann, L., Gysel, M., Weingartner, E., Baltensperger, U., Lohmann, U., and Cziczo, D. J.: In situ determination of atmospheric aerosol composition as a function of hygroscopic growth, J. Geophys. Res.-Atmos., 113, D16213, https://doi.org/10.1029/2008JD009954, 2008.

Heringa, M., DeCarlo, P., Chirico, R., Tritscher, T., Dommen, J., Weingartner, E., Richter, R., Wehrle, G., Prévôt, A., and Baltensperger, U.: Investigations of primary and secondary particulate matter of different wood combustion appliances with a high-resolution time-of-flight aerosol mass spectrometer, Atmos. Chem. Phys., 11, 5945-5957, https://doi.org/10.5194/acp11-5945-2011, 2011.

Herndon, S. C., Onasch, T. B., Wood, E. C., Kroll, J. H., Canagaratna, M. R., Jayne, J. T., Zavala, M. A., Knighton, W. B., Mazzoleni, C., and Dubey, M. K.: Correlation of secondary organic aerosol with odd oxygen in Mexico City, Geophys. Res. Lett., 35, L15804, https://doi.org/10.1029/2008GL034058, 2008.

Hu, W., Hu, M., Hu, W., Jimenez, J. L., Yuan, B., Chen, W., Wang, M., Wu, Y., Chen, C., and Wang, Z.: Chemical composition, sources, and aging process of submicron aerosols in Beijing: Contrast between summer and winter, J. Geophys. Res.-Atmos., 121, 1955-1977, https://doi.org/10.1002/2015JD024020, 2016.

Huang, X.-F., Sun, T.-L., Zeng, L.-W., Yu, G.-H., and Luan, S.-J.: Black carbon aerosol characterization in a coastal city in South China using a single particle soot photometer, Atmos. Environ., 51, 21-28, https://doi.org/10.1016/j.atmosenv.2012.01.056, 2012.

Huang, Y., Li, L., Li, J., Wang, X., Chen, H., Chen, J., Yang, X., Gross, D., Wang, H., and Qiao, L.: A case study of the highly time-resolved evolution of aerosol chemical and optical properties in urban Shanghai, China, Atmos. Chem. Phys., 13, 39313944, https://doi.org/10.5194/acp-13-3931-2013, 2013.

Johnson, G. R., Ristovski, Z. D., D’Anna, B., and Morawska, L.: Hygroscopic behavior of partially volatilized coastal marine aerosols using the volatilization and humidification tandem differential mobility analyzer technique. J. Geophys. Res., 110, D20203, https://doi.org/10.1029/2004JD005657, 2005.

Kondo, Y.: Effects of black carbon on climate: Advances in measurement and modeling, Monographs on Environment, Environ. Earth Planets, 3, 1-85, https://doi.org/10.5047/meep.2015.00301.0001, 2015.

Kondo, Y., Komazaki, Y., Miyazaki, Y., Moteki, N., Takegawa, N., Kodama, D., Deguchi, S., Nogami, M., Fukuda, M., and Miyakawa, T.: Temporal variations of elemental carbon in Tokyo, J. Geophys. Res.-Atmos., 111, D12205, https://doi.org/10.1029/2005JD006257, 2006.

Kuwata, M. and Kondo, Y.: Dependence of size-resolved CCN spectra on the mixing state of nonvolatile cores observed in Tokyo, J. Geophys. Res., 113, D19202, https://doi.org/10.1029/2007JD009761, 2008.

Kuwata, M., Kondo, Y., Mochida, M., Takegawa, N., and Kawamura, K.: Dependence of CCN activity of less volatile particles 
on the amount of coating observed in Tokyo, J. Geophys. Res., 112, D11207, https://doi.org/10.1029/2006JD007758, 2007.

Kroll, J. H. and Seinfeld, J. H.: Chemistry of secondary organic aerosol: Formation and evolution of low-volatility organics in the atmosphere, Atmos. Environ., 42, 3593-3624, https://doi.org/10.1016/j.atmosenv.2008.01.003, 2008.

Löndahl, J., Massling, A., Pagels, J., Swietlicki, E., Vaclavik, E., and Loft, S.: Size-resolved respiratory-tract deposition of fine and ultrafine hydrophobic and hygroscopic aerosol particles during rest and exercise, Inhal. Toxicol., 19, 109-116, https://doi.org/10.1080/08958370601051677, 2007.

Laborde, M., Crippa, M., Tritscher, T., Jurányi, Z., Decarlo, P., Temime-Roussel, B., Marchand, N., Eckhardt, S., Stohl, A., and Baltensperger, U.: Black carbon physical properties and mixing state in the European megacity Paris, Atmos. Chem. Phys., 13, 5831-5856, https://doi.org/10.5194/acp-13-5831-2013, 2013.

Lammel, G. and Novakov, T.: Water nucleation properties of carbon-black and diesel soot particles, Atmos. Environ., 29, 813823, 1995.

Leskinen, A. P., Jokiniemi, J. K., and Lehtinen, K. E.: Characterization of aging wood chip combustion aerosol in an environmental chamber, Atmos. Environ., 41, 3713-3721, https://doi.org/10.1016/j.atmosenv.2006.12.016, 2007.

Lewis, K. A., Arnott, W. P., Moosmuller, H., Chakrabarty, R. K., and Mishchenko, M. I.: Reduction in biomass burning aerosol light absorption upon humidification: roles of inorganicallyinduced hygroscopicity, particle collapse, and photoacoustic heat and mass transfer, Atmos. Chem. Phys., 9, 8949-8966, https://doi.org/10.5194/acp-9-8949-2009, 2009.

Li, H., Zhang, Q., Zhang, Q., Chen, C., Wang, L., Wei, Z., Zhou, S., Parworth, C., Zheng, B., and Canonaco, F.: Wintertime aerosol chemistry and haze evolution in an extremely polluted city of the North China Plain: significant contribution from coal and biomass combustion, Atmos. Chem. Phys., 17, 4751-4768, https://doi.org/10.5194/acp-17-4751-2017, 2017.

Li, L., Huang, Z., Dong, J., Li, M., Gao, W., Nian, H., Fu, Z., Zhang, G., Bi, X., and Cheng, P.: Real time bipolar time-of-flight mass spectrometer for analyzing single aerosol particles, Int. J. Mass Spectrom., 303, 118-124, https://doi.org/10.1016/j.ijms.2011.01.017, 2011.

Liu, D., Allan, J., Whitehead, J., Young, D., Flynn, M., Coe, H., McFiggans, G., Fleming, Z. L., and Bandy, B.: Ambient black carbon particle hygroscopic properties controlled by mixing state and composition, Atmos. Chem. Phys., 13, 2015-2029, https://doi.org/10.5194/acp-13-2015-2013, 2013.

Liu, D., Allan, J. D., Young, D. E., Coe, H., Beddows, D., Fleming, Z. L., Prevot, A. S.: Size distribution, mixing state and source apportionment of black carbon aerosol in London during wintertime, Atmos. Chem. Phys., 14, 10061-10084, https://doi.org/10.5194/acp-14-10061-2014, 2014.

Matsui, H., Koike, M., Kondo, Y., Moteki, N., Fast, J. D., and Zaveri, R. A.: Development and validation of a black carbon mixing state resolved three-dimensional model: Aging processes and radiative impact, J. Geophys. Res.-Atmos., 118, 2304-2326, https://doi.org/10.1029/2012JD018446, 2013.

McMeeking, G. R., Hamburger, T., Liu, D., Flynn, M., Morgan, W. T., Northway, M., Highwood, E. J., Krejci, R., Allan, J. D., Minikin, A., and Coe, H.: Black carbon measurements in the boundary layer over western and northern Europe, At- mos. Chem. Phys., 10, 9393-9414, https://doi.org/10.5194/acp10-9393-2010, 2010.

McMeeking, G., Good, N., Petters, M., McFiggans, G., and Coe, H.: Influences on the fraction of hydrophobic and hydrophilic black carbon in the atmosphere, Atmos. Chem. Phys., 11, 5099-5112, https://doi.org/10.5194/acp-11-5099-2011, 2011.

Moffet, R. C., de Foy, B., Molina, L. T., Molina, M. J., and Prather, K. A.: Measurement of ambient aerosols in northern Mexico City by single particle mass spectrometry, Atmos. Chem. Phys., 8, 4499-4516, https://doi.org/10.5194/acp-8-4499-2008, 2008.

Mogili, P. K., Kleiber, P. D., Young, M. A., and Grassian, V. H.: $\mathrm{N}_{2} \mathrm{O}_{5}$ hydrolysis on the components of mineral dust and sea salt aerosol: Comparison study in an environmental aerosol reaction chamber, Atmos. Environ., 40, 7401-7408, https://doi.org/10.1016/j.atmosenv.2006.06.048, 2006.

Moteki, N. and Kondo, Y.: Dependence of laser-induced incandescence on physical properties of black carbon aerosols: Measurements and theoretical interpretation, Aerosol Sci. Tech., 44, 663675, https://doi.org/10.1080/02786826.2010.484450, 2010.

Mozurkewich, M. and Calvert, J. G.: Reaction probability of $\mathrm{N}_{2} \mathrm{O}_{5}$ on aqueous aerosols, J. Geophys. Res.-Atmos., 93, 1588915896, https://doi.org/10.1029/JD093iD12p15889, 1988.

Pagels, J., Khalizov, A. F., McMurry, P. H., and Zhang, R. Y.: Processing of soot by controlled sulphuric acid and water condensation-Mass and mobility relationships, Aerosol Sci. Technol., 43, 629-640, https://doi.org/10.1080/02786820902810685, 2009.

Pathak, R. K., Wu, W. S., and Wang, T.: Summertime $\mathrm{PM}_{2.5}$ ionic species in four major cities of China: nitrate formation in an ammonia-deficient atmosphere, Atmos. Chem. Phys., 9, 17111722, https://doi.org/10.5194/acp-9-1711-2009, 2009.

Petzold, A., Gysel, M., Vancassel, X., Hitzenberger, R., Puxbaum, H., Vrochticky, S., Weingartner, E., Baltensperger, U., and Mirabel, P.: On the effects of organic matter and sulphur containing compounds on the $\mathrm{CCN}$ activation of combustion particles, Atmos. Chem. Phys., 5, 3187-3203, https://doi.org/10.5194/acp5-3187-2005, 2005.

Pratt, K., Murphy, S., Subramanian, R., DeMott, P., Kok, G., Campos, T., Rogers, D., Prenni, A., Heymsfield, A., and Seinfeld, J.: Flight-based chemical characterization of biomass burning aerosols within two prescribed burn smoke plumes, Atmos. Chem. Phys., 11, 12549-12565, https://doi.org/10.5194/acp-1112549-2011, 2011.

Qin, X., Pratt, K. A., Shields, L. G., Toner, S. M., and Prather, K. A.: Seasonal comparisons of single-particle chemical mixing state in Riverside, CA, Atmos. Environ., 59, 587-596, https://doi.org/10.1016/j.atmosenv.2012.05.032, 2012.

Reid, J., Koppmann, R., Eck, T., and Eleuterio, D.: A review of biomass burning emissions part II: intensive physical properties of biomass burning particles, Atmos. Chem. Phys., 5, 799-825, https://doi.org/10.5194/acp-5-799-2005, 2005.

Riemer, N., Vogel, H., and Vogel, B.: Soot aging time scales in polluted regions during day and night, Atmos. Chem. Phys., 4, 1885-1893, https://doi.org/10.5194/acp-4-1885-2004, 2004.

Rose, D., Gunthe, S. S., Su, H., Garland, R. M., Yang, H., Berghof, M., Cheng, Y. F., Wehner, B., Achtert, P., Nowak, A., Wiedensohler, A., Takegawa, N., Kondo, Y., Hu, M., Zhang, Y., Andreae, M. O., and Pöschl, U.: Cloud condensation nuclei in polluted air and biomass burning smoke near the megac- 
ity Guangzhou, China - Part 2: Size-resolved aerosol chemical composition, diurnal cycles, and externally mixed weakly CCN-active soot particles, Atmos. Chem. Phys., 11, 2817-2836, https://doi.org/10.5194/acp-11-2817-2011, 2011.

Schneider, J., Hock, N., Weimer, S., Borrmann, S., Kirchner, U., Vogt, R., and Scheer, V.: Nucleation particles in diesel exhaust: Composition inferred from in situ mass spectrometric analysis, Environ. Sci. Technol., 39, 6153-6161, https://doi.org/10.1021/es049427m, 2005.

Schwarz, J. P., Gao, R. S., Fahey, D. W., Thomson, D. S., Watts, L. A., Wilson, J. C., Reeves, J. M., Darbeheshti, M., Baumgardner, D. G., Kok, G. L., Chung, S. H., Schulz, M., Hendricks, J., Lauer, A., Karcher, B., Slowik, J. G., Rosenlof, K. H., Thompson, T. L., Langford, A. O., Loewenstein, M., and Aikin, K. C.: Single-particle measurements of midlatitude black carbon and light-scattering aerosols from the boundary layer to the lower stratosphere, J. Geophys. Res., 111, D16207, https://doi.org/10.1029/2006JD007076, 2006.

Shiraiwa, M., Kondo, Y., Moteki, N., Takegawa, N., Miyazaki, Y., and Blake, D.: Evolution of mixing state of black carbon in polluted air from Tokyo, Geophys. Res. Lett., 34, L16803, https://doi.org/10.1029/2007GL029819, 2007.

Sjogren, S., Gysel, M., Weingartner, E., Alfarra, M. R., Duplissy, J., Cozic, J., Crosier, J., Coe, H., and Baltensperger, U.: Hygroscopicity of the submicrometer aerosol at the high-alpine site Jungfraujoch, $3580 \mathrm{~m}$ a.s.1., Switzerland, Atmos. Chem. Phys., 8, 5715-5729, https://doi.org/10.5194/acp-8-5715-2008, 2008.

Slowik, J. G., Stainken, K., Davidovits, P., Williams, L., Jayne, J., Kolb, C., Worsnop, D. R., Rudich, Y., DeCarlo, P. F., and Jimenez, J. L.: Particle morphology and density characterization by combined mobility and aerodynamic diameter measurements. Part 2: Application to combustion-generated soot aerosols as a function of fuel equivalence ratio, Aerosol Sci. Technol., 38, 1206-1222, https://doi.org/10.1080/027868290903916, 2004.

Song, X.-H., Hopke, P. K., Fergenson, D. P., and Prather, K. A.: Classification of single particles analyzed by ATOFMS using an artificial neural network, ART-2A, Anal. Chem., 71, 860-865, https://doi.org/10.1021/ac9809682, 1999.

Soto-Garcia, L. L., Andreae, M. O., Andreae, T. W., Artaxo, P., Maenhaut, W., Kirchstetter, T., Novakov, T., Chow, J. C., and Mayol-Bracero, O. L.: Evaluation of the carbon content of aerosols from the burning of biomass in the Brazilian Amazon using thermal, optical and thermal-optical analysis methods, Atmos. Chem. Phys., 11, 4425-4444, https://doi.org/10.5194/acp11-4425-2011, 2011.

Spencer, M. T., Shields, L. G., and Prather, K. A.: Simultaneous measurement of the effective density and chemical composition of ambient aerosol particles, Environ. Sci. Technol., 41, 13031309, https://doi.org/10.1021/es061425+, 2007.

Stokes, R. and Robinson, R.: Interactions in aqueous nonelectrolyte solutions. I. Solute-solvent equilibria, J. Phys. Chem., 70, 2126 2131, https://doi.org/10.1021/j100879a010, 1966.

Swietlicki, E., Hansson, H. C., Hämeri, K., Svenningsson, B., Massling, A., McFiggans, G., McMurry, P., Petäjä, T., Tunved, P., and Gysel, M.: Hygroscopic properties of submicrometer atmospheric aerosol particles measured with H-TDMA instruments in various environments - A review, Tellus B, 60, 432-469, https://doi.org/10.1111/j.1600-0889.2008.00350.x, 2008.
Topping, D., McFiggans, G., and Coe, H.: A curved multicomponent aerosol hygroscopicity model framework: Part 2 - Including organic compounds, Atmos. Chem. Phys., 5, 1223-1242, https://doi.org/10.5194/acp-5-1223-2005, 2005a.

Topping, D., McFiggans, G., and Coe, H.: A curved multicomponent aerosol hygroscopicity model framework: Part 1Inorganic compounds, Atmos. Chem. Phys., 5, 1205-1222, https://doi.org/10.5194/acp-5-1205-2005, 2005 b.

Varutbangkul, V., Brechtel, F., Bahreini, R., Ng, N., Keywood, M., Kroll, J., Flagan, R., Seinfeld, J., Lee, A., and Goldstein, A.: Hygroscopicity of secondary organic aerosols formed by oxidation of cycloalkenes, monoterpenes, sesquiterpenes, and related compounds, Atmos. Chem. Phys., 6, 2367-2388, https://doi.org/10.5194/acp-6-2367-2006, 2006.

Wang, D., Zhou, B., Fu, Q., Zhao, Q., Zhang, Q., Chen, J., Yang, X., Duan, Y., and Li, J.: Intense secondary aerosol formation due to strong atmospheric photochemical reactions in summer: observations at a rural site in eastern Yangtze River Delta of China, Sci. Total Environ., 571, 1454-1466, https://doi.org/10.1016/j.scitotenv.2016.06.212, 2016a.

Wang, Q., Huang, R.-J., Zhao, Z., Zhang, N., Wang, Y., Ni, H., Tie, X., Han, Y., Zhuang, M., and Wang, M.: Size distribution and mixing state of refractory black carbon aerosol from a coastal city in South China, Atmos. Res., 181, 163-171, https://doi.org/10.1016/j.atmosres.2016.06.022, 2016 b.

Wang, X., Zhang, Y., Chen, H., Yang, X., Chen, J., and Geng, F.: Particulate nitrate formation in a highly polluted urban area: a case study by single-particle mass spectrometry in Shanghai, Environ. Sci. Technol., 43, 3061-3066, https://doi.org/10.1021/es8020155, 2009.

Wang, X., Williams, B. J., Wang, X., Tang, Y., Huang, Y., Kong, L., Yang, X., and Biswas, P.: Characterization of organic aerosol produced during pulverized coal combustion in a drop tube furnace, Atmos. Chem. Phys., 13, 10919-10932, https://doi.org/10.5194/acp-13-10919-2013, 2013.

Wang, X., Ye, X., Chen, H., Chen, J., Yang, X., and Gross, D. S.: Online hygroscopicity and chemical measurement of urban aerosol in Shanghai, China, Atmos. Environ., 95, 318-326, https://doi.org/10.1016/j.atmosenv.2014.06.051, 2014.

Weingartner, E., Burtscher, H., and Baltensperger, U.: Hygroscopic properties of carbon and diesel soot particles, Atmos. Environ., 31, 2311-2327, https://doi.org/10.1016/S1352-2310(97)00023X, 1997.

Winkler, P.: The growth of atmospheric aerosol particles as a function of the relative humidity - II. An improved concept of mixed nuclei, J. Aerosol Sci., 4, 373-387, https://doi.org/10.1016/00218502(73)90027-X, 1973.

Wood, E., Canagaratna, M., Herndon, S., Onasch, T., Kolb, C., Worsnop, D., Kroll, J., Knighton, W., Seila, R., and Zavala, M.: Investigation of the correlation between odd oxygen and secondary organic aerosol in Mexico City and Houston, Atmos. Chem. Phys., 10, 8947-8968, https://doi.org/10.5194/acp10-8947-2010, 2010.

Xue, J., Li, Y., Wang, X., Durbin, T. D., Johnson, K. C., Karavalakis, G., Asa-Awuku, A., Villela, M., Quiros, D., $\mathrm{Hu}, \mathrm{S}$., and Huai, T.: Comparison of vehicle exhaust particle size distributions measured by SMPS and EEPS during steady-state conditions, Aerosol Sci. Technol., 49, 984-996, https://doi.org/10.1080/02786826.2015.1088146, 2015. 
Ye, X., Tang, C., Yin, Z., Chen, J., Ma, Z., Kong, L., Yang, X., Gao, W., and Geng, F.: Hygroscopic growth of urban aerosol particles during the 2009 Mirage-Shanghai Campaign, Atmos. Environ., 64, 263-269, https://doi.org/10.1016/j.atmosenv.2012.09.064, 2013.

Zelenyuk, A., Imre, D., Han, J.-H., and Oatis, S.: Simultaneous Measurements of Individual Ambient Particle Size, Composition, Effective Density, and Hygroscopicity, Anal. Chem., 80, 1401-1407, 2008.

Zervas, E. and Dorlhene, P.: Comparison of exhaust particle number measured by EEPS, CPC, and ELPI, Aerosol Sci. Technol., 40, 977-984, https://doi.org/10.1080/02786820600844093, 2006.

Zhai, J., Lu, X., Li, L., Zhang, Q., Zhang, C., Chen, H., Yang, X., and Chen, J.: Size-resolved chemical composition, effective density, and optical properties of biomass burning particles, Atmos. Chem. Phys., 17, 7481-7493, https://doi.org/10.5194/acp17-7481-2017, 2017.
Zhang, C., Lu, X., Zhai, J., Chen, H., Yang, X., Zhang, Q., Zhao, Q., Fu, Q., Sha, F., and Jin, J.: Insights into the formation of secondary organic carbon in the summertime in urban Shanghai, J. Environ. Sci., 72, 118-132, https://doi.org/10.1016/j.jes.2017.12.018, 2018.

Zhang, G., Bi, X., He, J., Chen, D., Chan, L. Y., Xie, G., Wang, X., Sheng, G., Fu, J., and Zhou, Z.: Variation of secondary coatings associated with elemental carbon by single particle analysis, Atmos. Environ., 92, 162-170, https://doi.org/10.1016/j.atmosenv.2014.04.018, 2014.

Zhang, R. Y., Khalizov, A. F., Pagels, J., Zhang, D., Xue, H., and McMurry, P. H.: Variability in morphology, hygroscopicity, and optical properties of soot aerosols during atmospheric processing, P. Natl. Acad. Sci. USA, 105, 10291-10296, https://doi.org/10.1073/pnas.0804860105, 2008. 